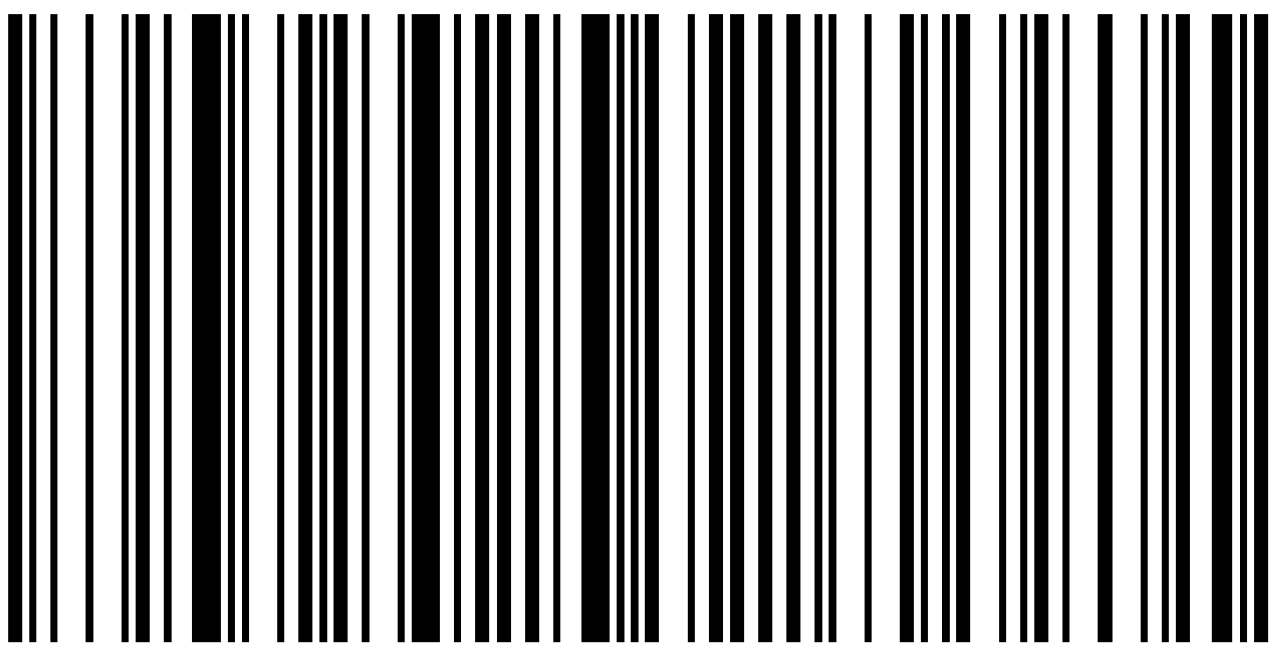

\title{
Codes of life: identification codes and the machine-readable
} world

\section{Martin Dodge 9 \\ Centre for Advanced Spatial Analysis, University College London, 1-19 Torrington Place, London WC1E 7HP, England}

\section{Rob Kitchin}

Department of Geography, National University of Ireland, Maynooth, County Kildare, Ireland; e-mail: rob.kitchin@may.ie

Received 8 March 2004; in revised form 7 June 2004

\begin{abstract}
In this paper we present a detailed examination of identification codes, their embeddedness in everyday life, and how recent trends are qualitatively altering their nature and power. Developing a Foucaultian analysis we argue that identification codes are key components of governmentality and capitalism. They provide a means of representing, collating, sorting, categorising, matching, profiling, regulating, of generating information, knowledge, and control through processes of abstraction, computation, modeling, and classification. Identification codes now provide a means of uniquely addressing all the entities and processes that make up everyday life - people, material objects, information, transactions, and territories. Moreover, they provide a means of linking these entities and processes together in complex ways to form dense rhizomic assemblages of power/knowledge. At present, however, the information that identification codes provide access to are, at best, oligopticon in nature-that is, they afford only partial and selective views. In the latter part of the paper we outline four trends-wide-scale trawling for data, increased granularity, forever storage, and enhanced processing and analysis - that seek to convert these partial oligopticons into more panoptic arrangements. In turn, we contend that these trends are part of a larger metatrend - the creation of a machine-readable world in which identification codes can be systematically and automatically 'read' and acted on by software independent of human control. This metatrend is supported by interlocking discourses such as safety, security, efficiency, antifraud, citizenship and consumer empowerment, productivity, reliability, flexibility, economic rationality, and competitive advantage to construct powerful, supportive discursive regimes.
\end{abstract}




\section{Introduction}

April 2003 marked the fiftieth anniversary of the discovery of the double helix structure of DNA, unlocking the fundamental genetic code of life (Watson and Crick, 1953). Like the DNA sequences that are unique to each individual, there now exists a plethora of unique codes that correspond to, and represent, individuals. These are the myriad of often taken-for-granted identification codes that are used on an everyday basis (for example, bank account and credit card numbers, passport numbers, social security numbers, computer passwords, and so on). Similarly, material objects are increasingly assigned unique identifiers that allow them to be processed, shipped, and traced through complex logistical networks (for example, manufacturer serial numbers, barcodes, order numbers, shipping numbers, vehicle license plates). People, objects, information, and transactions can be tied to territorial location through another set of codes (for example, grid references, latitude and longitude, postal codes, enumeration district identifiers, and geodemographic area types). These identification codes are tangible links into the rhizomatic assemblages of bureaucratic information, logistics, surveillance, and security, in which people increasing live and interact. Although many are banal and are treated ambivalently, identification codes are increasingly vital to everyday interactions, transactions, and mobilities. They are essential referents for government agencies and institutions for managing and monitoring populations, and for businesses for logistics, accounting, and so-called 'customer-relations management' systems. Their power lies in their utility as devices for representing, collating, sorting, monitoring, matching, profiling, and the fact that they allow analytical processes of abstraction, computation, modeling, classification - of generating information and knowledge. They can be used to search, sift, differentiate, and regulate complex systems, to provide competitive advantage, to target markets, to reduce real and perceived risks, and enable finer grained 'social sorting' (Lyon, 2003a). They provide the practical means for dealing with vast, complex sets of information and for drawing sense from these sets.

To structure the discussion, the paper is divided into four sections. In the first section we provide an introduction to identification codes and their workings. In the second, we outline their importance by employing a Foucaultian framework to illustrate their utility and power. In the third section we use a simple typology to provide an illustrative overview of five sets of identification codes-people, object, information, transaction, and territorial. In the fourth section, we examine four recent trends that are transforming the scope, utility, and power of identification codes: the drive towards capturing the maximum amount of information as possible, facilitated by the transference from 'dumb' to 'smart' technologies, new dynamic means of monitoring entities, and the mobile tracking of entities; the drive towards finer resolution input and in particular the development of unique identifiers that are infallible; the development of cheap and efficient long-term storage of digital records; and enhanced means of linking datasets and more sophisticated and precise methods of processing and analysis. These trends, we posit, are the result of a larger metatrend: the move towards a machine-readable world - that is, a move to apply identification codes to all entities by using media that can be 'read' and acted on by software independent of human control.

\section{Identification codes}

Identification is the process of telling like things apart. In practical terms it is the ability to pinpoint correctly a particular individual or item from a group. Once pinpointed and identified, this entity can be worked upon, processed in some fashion that differs from the group as a whole. Consequently, processes of identification are intimately bound to processes of differentiation, wherein the mass is separated into 
individual or other units of manageable size. Further, this disaggregation also allows those managing the identification system to reaggregate individuals along new axes of similarity that suit their purposes (such as a retailer grouping similar customers together in terms of their consumption patterns). Identification in practice is achieved through labels, tokens, and names, and increasingly consists of unique identification codes - that is, strings of numbers and letters. These unique codes are generated automatically by mathematical algorithms using software programs and can be tracked by sophisticated information systems. In many real-time data-processing systems (for example, banking and stock markets, air-traffic control) billions of transactions can be logged each day, each transaction encoded with unique identifiers that usually include the time, date, and place of the transaction.

The key characteristics of identification code numbers are their form (length and formatting), their granularity, and the extent of recognition and reputation. Code numbers can be defined by the creator of the system to be any length, particularly when they are only ever handled by computers. Where identification codes are used to authorise access to significant resources (especially money), then code length can be significant in determining security. Many identification code numbers used in business and telecommunications are very long indeed (figure 1). Codes also vary as a function of the type of valid characters they can contain-numeric, alphabetic. With regards to granularity, the most obvious level for people is that of the individual. For objects, information, and spaces, granularity is more problematic. For example, spaces vary as a function of scale (for example, households, neighbourhoods, districts, towns, regions, and so on). The granularity of codes provides different levels of resolution, with the trend to increasing granularity, thus maximising resolution. Finally, codes vary in their

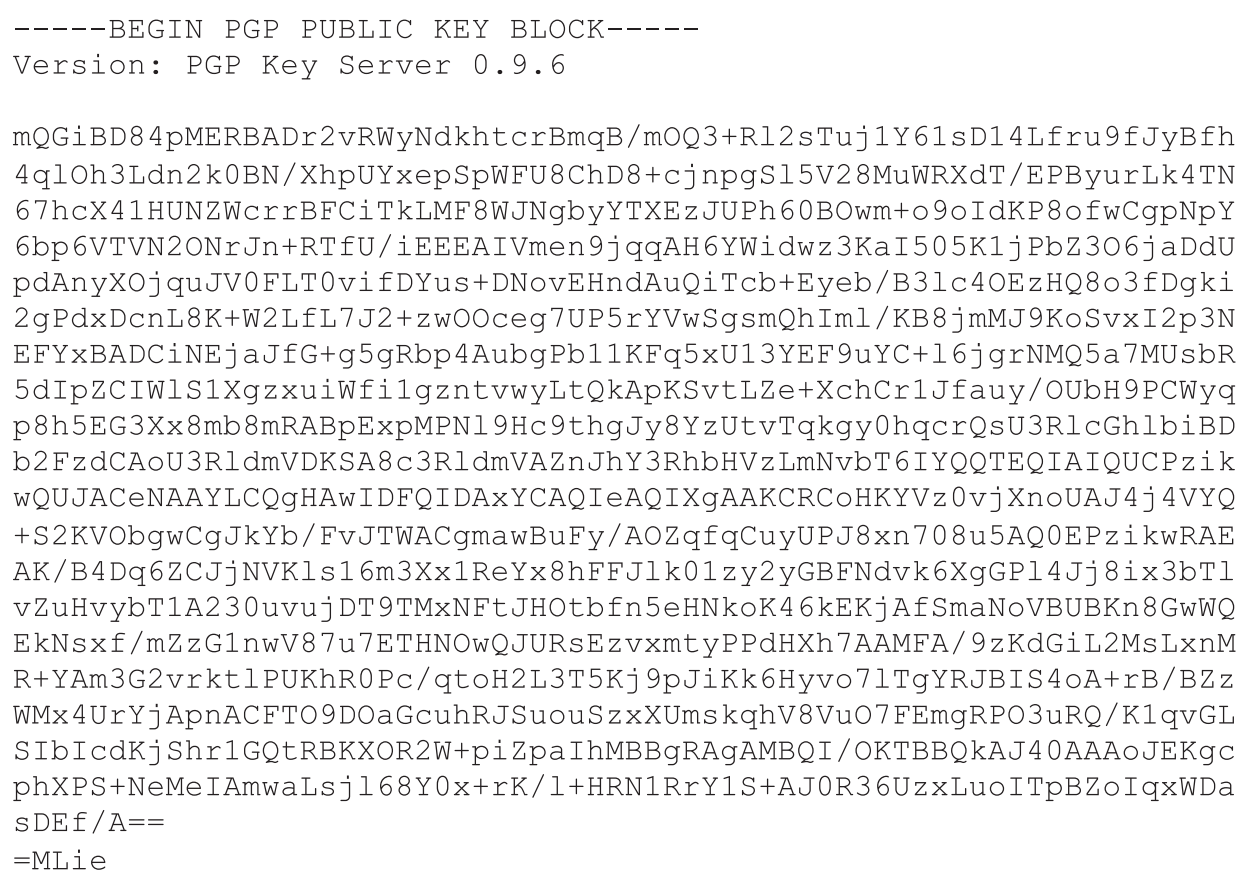

Figure 1. A 1024-bit public key used for encrypting messages for secure e-mail communication using the Pretty-Good Privacy software. This identification code provides a digital signature which effectively authenticates the sender (courtesy of Steve Coast). 
ability to be recognised temporally, geographically, and institutionally. Some codes are long lasting and recognised globally (often coordinated through ISO, the International Organization for Standardization), whereas others only work within a more localised context - for example, within a given office or institution.

In combination, these identification codes-for people, objects, information, transactions, and territories - are, we contend, key capta. Jensen (1950 cited in Becker, 1952) details that capta are units of data that have been selected and harvested from the sum of all potential data. Here, data (derived from the Latin dare, meaning 'to give') are the total sum of facts that an entity can potentially 'give' to government or business or whomever is constructing a database. Capta (derived from the Latin capere, meaning 'to take') are those facts that those constructing the database decide to 'take' given that they cannot record or store everything. ${ }^{(1)}$ They are elements of the continuous material-social reality of everyday life that are most easily intelligible and distinguishable. Capta thus have a specific form, specific modes of representation, purposes, are meaningful to the agency that selected them, and have contexts (Alexander, 2002). Capta are inherently partial and selective, and the distinguishing criteria used thus have consequence.

Identification codes are key capta because they provide the ties that link together separate strands of capta. Capta are important in the contemporary setting of information-system design because when placed into a wider context, through say specific queries or forms of analysis, meaning is attributed to them, thus converting them into information (Checkland and Holwell, 1998; Haklay, 2001). When fields of information are combined to create larger, collective structures they become knowledge. Identification codes thus form the basis of a dense rhizomic assemblage. This assemblage constitutes what might be termed a 'capta shadow'(2) (capta that uniquely represent people, objects, information, and transactions) that often has associated 'capta trails' (records of the location of interactions and transactions) across space - time.

Conceptually, it is important to separate an identification code from the material media on which it is stored, moved, represented, and retrieved. The lines of the barcode, the magnetic strip on the credit card, and the chip in an electronic key are merely a means of holding the code in a convenient form for use. This separation is readily apparent when one considers the power of the credit card number versus the two by four inch plastic card that carries it. Although we are primarily concerned with identification codes and not with their carrying media in this paper, it is not to say they are unimportant. In certain instances the medium is a vital element in the operation of identification, helping to enhance the credentials of the issuer and the legitimacy of the code it carries, such as the multiple design features of passports that give them status and make them hard to forge.

(1) Jensen (1950, page ix, cited in Becker, 1952, page 278) states that "it is an unfortunate accident of history that the term datum ... rather than captum ... should have come to symbolize the unitphenomenon in science. For science deals, not with 'that which has been given' by nature to the scientist, but with 'that which has been taken' or selected from nature by the scientist in accordance with his purpose..." (emphasis in original).

(2) This idea of an individual having a 'shadow' inside information systems has been conceptualised by a number of scholars, in terms of a 'shadow order' (Bogard, 1996), 'digital persona' (Clarke, 1994a), 'dividuals' (Deleuze, 1992), and 'data doubles' (Lyon, 2003a). We choose the term 'capta shadow' as the metaphor of the shadow usefully conveys the idea that it is something you can never be get rid of. 


\section{The discursive regimes of identification codes}

As noted, the power of identification codes is derived from their ability to discriminate, to be rapidly and automatically monitored, updated, and processed, and to provide authentication and credentials that dictate various forms of access (for example, to a bank account, government services, or a location). Identification codes provide information systems with their technicity (Dodge and Kitchin, 2005; Mackenzie, 2002) - that is, the ability to be able to process the capta they hold. In contemporary Western society, consistent and accurate systems of identification are seen as vital, with the proliferation and growing density of identification codes and the technologies that produce and process them supported by multiple discourses that primarily relate to governmentality and capital accumulation (see Innes, 2001): codes are useful for both governing people and managing organisations.

\section{Governing people}

It is now widely acknowledged that the Enlightenment and the shift into a modern society was accompanied on the one hand by new, more systematic means of managing and governing populations, and on the other by a drive to scale and deliver a uniformity of service across whole populations (for example, law enforcement, health provision, tax assessment). As a consequence, people became increasingly viewed as components in larger systems, as labour commodities, as problems to be solved (for example, ill-health, criminality, illiteracy), and as citizens. As such, modernity required the 'quantification' of society - cataloguing and classification-much of which necessitated 'objective' means of identification and accurate measurement systems (see Alonso and Starr, 1987; Barnes and Hannah, 2001; Desrosières, 1998; Porter, 1995; Thrift, 2004; Wise, 1995).

Identification codes provided the operational means of identifying, verifying, and processing people by distant institutions and impersonal management systems as "other tokens of trust were sought, to make up for the lack of visual, body clues and cues, such as handshakes, eye contact, and so on" (Lyon, 2002, page 244). As such, there has been an ongoing shift from localised, subjective knowledges to centralised, objective ones. This modernist desire to 'order the world' thus required technical infrastructures of which systems of identification were a key part. As technologies advanced from handwritten registers and ledgers to the use of punch-card machinery, then to mainframe computer systems, and more recently distributed information systems, the ability to create and process vast quantities of capta in shorter and shorter time periods has progressed significantly. This has led to the development of assemblages of personal identification codes from passports, drivers' licences, national insurance or social security numbers, work identification cards, to bank and store loyalty cards, designed on the one hand to identify and authenticate their owner as 'trustworthy', and on the other to allow them to be 'managed' by the issuer of the card (for detailed reviews see Rule et al, 1983; Torpey, 2000; Torpey and Caplan, 2001).

In the writings of Foucault, particularly his genealogies (Foucault, 1976; 1978), the development of modern systems of population management-needed to propagate and sustain the emerging capitalist system and its associated industrialisation, urbanisation, and colonisation - provided an apparatus of regulation and 'technologies of the self'. Here, systems of regulation and management were devised to provide a detailed knowledge of a population, "... a way of rendering it into thought, so that it can be examined, evaluated, its ills diagnosed and solutions prescribed... . Such representation has two major aspects: the articulation of languages to describe the object of government and the invention of devices to inscribe it" (Rose, 1996, page 70, original emphasis). Here, the translation of individuals into the domain of knowledges - 'calculable people' - made 
it possible to govern according to norms defined and legitimated by the status of science, with professional elites able to ground their authority in an objective knowledge (Rose, 1996). Examples of these capta include censuses, health records, school attendance, criminal records, tax records, registration of births, deaths, marriages, and so on - all of which have grown enormously in volume and scope in recent decades.

The systems of regulation that identification codes bound individuals to are aimed to both discipline and self-discipline, by producing a particular form of rationality designed to ensure good government through a more efficient and rationalised legal and social field (McNay, 1994). These systems work to instil self-discipline because the mechanism of identification and monitoring threatens observation that is ever present; the potential pervasiveness of observation, combined with its effects, leads to selfregulation, changing the practices of governmentality. As Hannah (1992, page 53) points out, "Judgement must seem automatic and impartial, responsibility lies as completely as possible with the perpetrator." Within this context, disciplinary governmentality involves "a complex constellation of group control... (through censuses, bureaucracies, policies, and so forth), an archipelago of disciplinary institutions (schools, workplaces) and an otherwise anonymous territory dotted with millions of staging points (ATM's [automated teller machines], surveillance cameras, application forms)" (Hannah, 1997a, page 178).

Throughout modernity, as Hannah (1997b) notes, the panopticon effect of disciplinary forms of governmentality has been open to vertical (within an activity) and horizontal (across activities) fragmentation. That is, within an activity, observation, judgment, and enforcement have often been undertaken by different agencies who communicated imperfectly; across activities, different organisations for legal, institutional, or technical reasons have not easily been able to exchange or compare information (Hannah, 1997b). Latour (cited in Amin and Thrift, 2002, page 92) thus refers to the imperfect panopticon of government as an 'oligopticon'-consisting of multiple vantage points from above, below, and within - "a series of partial orders, localised totalities, with their ability to gaze in some directions and not others." As Hannah (1997b, page 352) states the "modern citizen [becomes] objectified in a life-path comprised of information, as a spatialised dossier.... For the average 'free' citizen the life-path ... is full of gaps, but retains its unity through the matchability of names, permanent addresses, social security numbers, etc."

The growing pervasiveness of identification codes and systems to match, trace, monitor, and regulate populations, however, transforms the oligopticon into a panopticon. Here, discourse is central as it provides the means through which to articulate, conceptualise, and justify governmental goals by making it seem as if common problems are being addressed through shared logic and principles. The justification for the present proliferation of identification codes thus draws on discourses of safety, security, efficiency (the 'best value' mantra in public-service provision in the United Kingdom), antifraud, and citizenship and consumer empowerment (which provides citizens with more access to government and governmental services and resources) delivered through a variety of agencies and structures. ${ }^{(3)}$ Innes (2001) also notes the importance of key symbolic events in discourses; for example, in the case of security surveillance, there are the 'signal crimes' "whose mediated coverage is constructed in such a way as to connotatively and denotatively signal to society that there is a 'public problem' that needs addressing." The attacks of $9 / 11$ are the most obvious signal crimes of recent decades. It is important to note, contra Foucault, that these discourses work

(3) The April 2004 government consultation document on the introduction of a national biometric identification card scheme in the United Kingdom provides a textbook example of the articulation of these techno-ideological discourses (Home Office, 2004). 
not simply because they act to discipline but because they also seduce. In Althusser's (1971) terms, these discourses thus interpellate by enticing people to subscribe to and desire their logic and to participate willingly and voluntarily in their ideology and practice (rather than simply disciplining them into docile bodies) (see Dodge and Kitchin, 2004).

\section{Managing organisations}

In tandem with the growth in systems designed to manage populations, there has been a drive to create highly ordered means of operating organisations such as civil services, the military, health care providers, local authorities, and businesses. To focus on the latter as illustration, modern business is predicated on systems of practice that work to ensure the maximisation of profits. These systems work to ensure efficiency, productivity (both with regards to workers and production systems), and competitive advantage. Over time the dominance of particular systems - for example, Fordist regimes of accumulation-have been replaced by new systems that take advantage of new technologies and new forms of transportation, communication, and information management. In recent years, the proliferation of distributed forms of communication such as the Internet and the development of complex information systems that can track and manage complex chains of components, commodities, and data are now widely acknowledged as having significant effects on the organisation of business globally (Castells, 1996; Dicken, 2003). Here, identification codes and their associated media are essential components. Identification codes, whether they be printed serial numbers, universal product codes in grocery barcodes, or other new kinds of 'smart' labels, provide a means of unambiguous identification and tracking - the knowing of what, when, and where of things at all times is the goal-and the ability to act on this knowledge with regards to sorting, aggregating, directing, linking, processing, and so on. Totally identified processes are seen to reduce the real and, more importantly, the perceived risks to business managers. Indeed, for business, they produce "A predictable world... a uniform cognitive entity with a structural centripetal tendency for more predictability over increasingly larger areas of human experience" (Lianos and Douglas, 2000, page 275).

Like the management of populations, new business systems and practices are driven by powerful discourses designed to discipline, seduce, and drive transformation, as capital, to use Harvey's (1982) phrase, seeks a new 'spatial fix' that will maximise profit. These discourses include efficiency, productivity, reliability, flexibility, economic rationality, and competitive advantage, each drawing off and reproducing management strategies and neoliberal ideology. Here, the rhetoric is that identification codes enable the automation of management, production, and logistical systems, making them more slimline and efficient; they allow for the speeding up of processing; they are highly reliable in reducing human error; they enable highly complex and flexible systems that can be automatically tracked and processed from a distance. In combination, these are used to argue that identification codes provide significant cost savings by reducing staff costs both through automation and by allowing businesses to take advantage of lower wages in different locations without losing quality or control. This in turn allows companies to gain competitive advantage over their rivals. As a consequence, many companies have been seduced by the power of wholesale application identification codes and have transformed their businesses, reorganising product manufacture, company administration, service delivery, and the ways in which they interact with customers and clients (for example, altering modes of payment through credit cards, introducing loyalty cards, utilising call centres, or using direct customer interfacing with information systems via the Internet). Indeed, a noteworthy feature of many 
interactions between individuals and businesses in contemporary Western society-the telephone query to a customer service centre being the archetypal example - is that they often begin with a 'reference number handshake' (the quoting of an account number or reference code to establish authenticity). Here, identification codes provide a means of authentication and accreditation replacing earlier forms of self-authentication and vouchsafing. For some interactions, especially financial ones, this often involves a lengthy series of identification codes and security phrases. These routine interactions are made personally identifiable and thus provide transaction-generated capta that enable customer profiling and targeted marketing. Indeed, there seems to be a drive in contemporary business practices in many sectors to remove the potential for anonymous transactions.

The ability to uniquely identify and track individuals has also led to changes in workplace practices by enabling increased security and the ability to monitor work patterns, productivity rates, and performance. For example, it is increasingly common for employees to be issued with work identity codes carried on cards: swipe cards, magnetic key fobs, or PINs (personal identification numbers) for keypads to regulate access to rooms and buildings; and usernames and passwords to access networked services. While these systems provide security they are also increasingly used as a means of workplace surveillance, to log and track worker whereabouts and performance-particularly in jobs where managers want quantitative measures of employee 'throughput' (for example, such as on a checkout or in a call centre).

\section{Types of identification codes: people, objects, information, transactions, and territories}

In this section we provide illustrative examples of different identification codes used for five different entity types to demonstrate the sophisticated nature, scope, and employment of current codes. In each case, the examples we detail are digital machine-readable codes.

\section{Personal codes}

"As every man goes through life he fills in a number of forms for the record, each containing a number of questions. A man's answer to one question on one form becomes a little thread, permanently connecting him to the local centre of personnel records administration. There are thus hundreds of little threads radiating from every man, millions of threads in all. If all these threads were suddenly to become visible, the whole sky would look like a spider's web... . They are not visible, they are not material, but every man is constantly aware of their existence.... Each man, permanently aware of his own invisible threads, naturally develops a respect for the people who manipulate the threads..."

Solzhenitsyn (1968, pages 223-224)

"I am not a number, I am a free man!"

Patrick McGoohan, 1960s television show The Prisoner

Nowadays, most people in Western societies are shadowed by a voluminous and evergrowing number of personalised records in the databases and customer-management systems of the businesses, organisations, and government agencies that service modern living. On their own, everyday routine computer-mediated economic transactions (for example, credit card use) entangle the life of each person into a denser web of threads, across time and space, than Solzhenitsyn could have imagined when he wrote the above quotation in 1968. This is supplemented by many other systems as more and more daily activities come to require personal identification codes in order to take place.

The proliferation of codes means that individuals are effectively accompanied by a parallel capta shadow. Capta shadows are the digital version of Solzhenitsyn's threads - the personal records and transaction-generated capta held about an individual by institutions and businesses. Although an individual's capta shadow is probably 
best characterised as multiple capta shadows to paraphrase McGoohan's character in The Prisoner, individuals are not just a number but many numbers - with the records held by one organisation not necessarily visible to another-it is true to say that the capta shadow for each individual is sizable and growing. Indeed, a capta shadow is inevitable and necessary to be able to function in contemporary society-for example, to work legitimately and pay taxes, to access government services, to travel, or to buy commodities (Clarke, 1994a; Lyon, 2002). That is not to say that capta shadows do not have their consequences with regards to privacy, confidentiality, and civil rights see, for example, Gandy's (1993) analysis. For example, individual capta shadows are now routinely used to 'socially sort' individuals, to evaluate perceived worth and risk through activities such as customer profiling, crime profiling, and constructing credit ratings (Graham, 2004; Leyshon and Thrift, 1999; Lyon, 2003a). The judgments are made auto-matically in software environments such that "... the user cannot negotiate with the system" (Lianos and Douglas, 2000, page 264). Consequently, Stalder (2002, page 120) notes,

"... this shadow body does more than follow us. It has also begun to precede us.

Before we arrive somewhere, we have already been measured and classified. Thus, upon arrival, we're treated according to whatever criteria has been connected to the profile that represents us."

Although individuals actively produce their capta shadow through their actions and transactions, they do not have full control over its form, extent, or how it is used. Moreover, capta shadows have become valuable, tradable commodities as evidenced by the growth of credit reference agencies, lifestyle profiles, and geodemographics systems (Goss, 1995; Larson, 1992). Personal identification codes are important here as they are the means by which an individual and his or her capta shadow are continually and consistently bound together; he or she can no more be separated from it than be separated from his or her physical shadow cast on a sunny day. In their digital form they make people machine-readable. Clarke (1994b) has classified personal identification coding systems into three general types: (1) 'something you have' (a physical token such as a passport); (2) 'something you know' (for example, a password or PIN); (3) 'something you are' (for example, physical characteristics, particularly the face).

It is possible to illustrate these codes and an individual's capta shadow by deconstructing a wallet, and identifying all the codes contained within on any given day. As table 1 reveals, the wallet contains identification codes relating to personal identity and authentication, financial accounts, travel, consumption, security (many of which are imposed and used without our knowledge, starting from birth). Other such individual codes can be found by sorting through routine domestic bills and statements. The personal identification codes in table 1 (over), with the exception of the photograph on the work identification card, are forms of Clarke's first type of identification coding system. However, there is increasing interest in the third type of personal identifier, 'something you are', and later in the paper we discuss in detail the development and use of new biometric identification systems.

\section{Object codes}

"This little footprint ... has built a gigantic structure of improvements - of size and speed, of service, of less waste, of increased efficiency. This lousy little footprint is like the tip of an inverted pyramid, and everything spreads out from it."

Alan Haberman, Chairman of the Barcode Selection Committee, quoted in Leibowitz (1999, page 132)

Capta shadows are not confined to people, they also almost universally accompany objects. Like people, objects are assigned unique identification codes including 


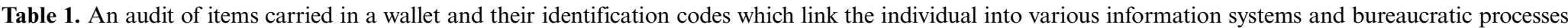
(source: Martin Dodge's wallet, 14 July 2003. Some code numbers have been randomly altered to preserve confidentiality, but their format remains the same)

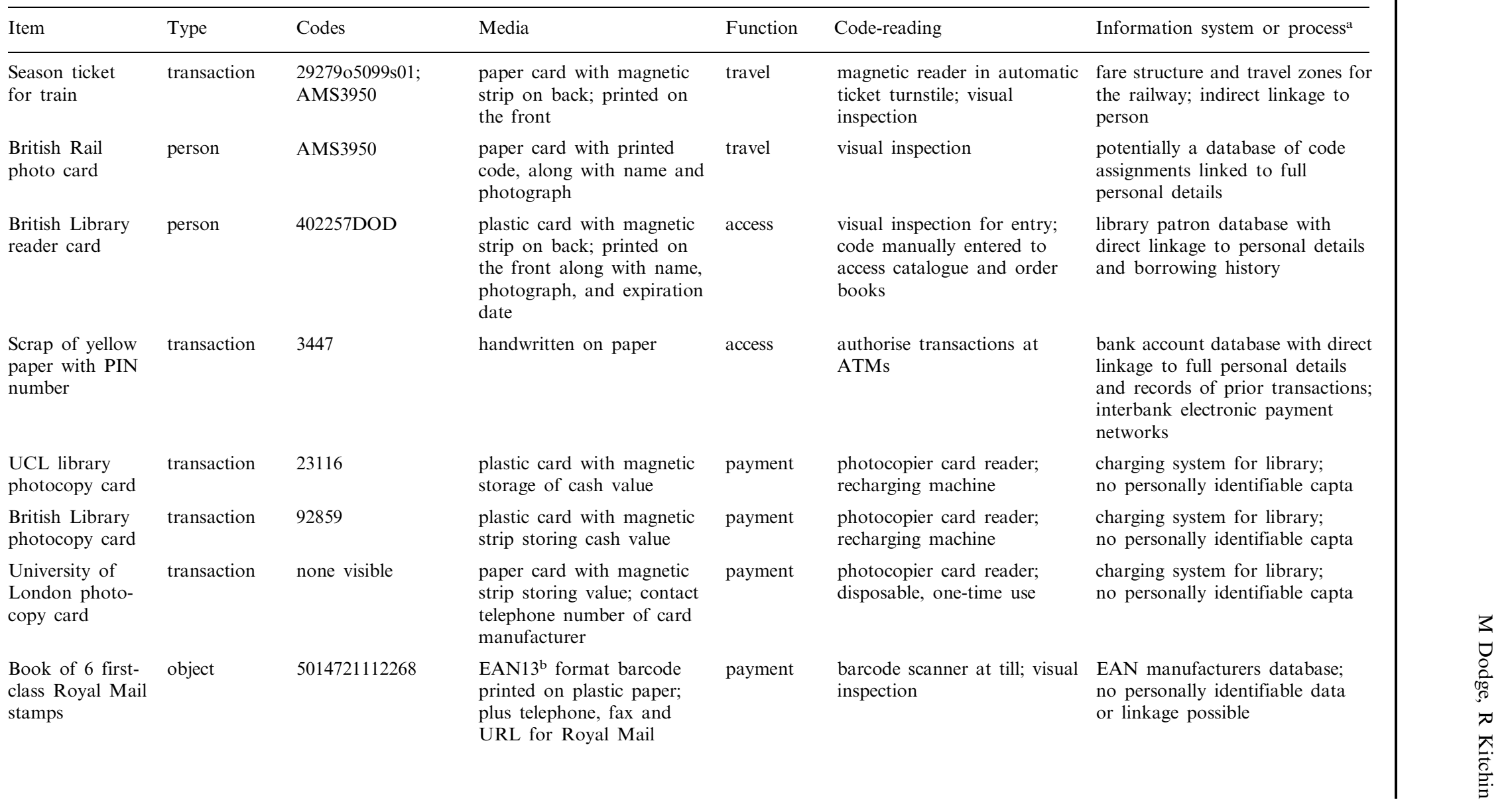


Table 1 (continued).

\begin{tabular}{|c|c|c|c|c|c|c|}
\hline Item & Type & Codes & Media & Function & Code-reading & Information system or process ${ }^{\mathrm{a}}$ \\
\hline $\begin{array}{l}\text { Promotional } \\
\text { business cards } \\
\text { for Atlas of } \\
\text { Cyberspace book }\end{array}$ & $\begin{array}{l}\text { object, } \\
\text { territorial }\end{array}$ & $\begin{array}{l}\text { ISBN } \\
(0201745755)\end{array}$ & $\begin{array}{l}\text { paper card with printed } \\
\text { codes; plus publisher } \\
\text { contact details (postal } \\
\text { codes, telephone/fax, URLs) }\end{array}$ & $\begin{array}{l}\text { informa- } \\
\text { ional }\end{array}$ & $\begin{array}{l}\text { enabled interested people } \\
\text { to obtain the book; ISBN } \\
\text { uniquely identifies the book }\end{array}$ & $\begin{array}{l}\text { publishing industry books in print } \\
\text { databases; contact details linked } \\
\text { to postal address systems, } \\
\text { telecommunications databases }\end{array}$ \\
\hline $\begin{array}{l}\text { Business card } \\
\text { (university } \\
\text { department) }\end{array}$ & $\begin{array}{l}\text { person, } \\
\text { territorial }\end{array}$ & $\begin{array}{l}\text { postal code (WC1E } \\
6 \mathrm{BT}) \text { telephone } \\
\text { number }(+44(0) 20 \\
76791255), \text { fax } \\
(+44(0) 207813 \\
2843), \text { e-mail } \\
\text { (m.dodge@ucl. } \\
\text { ac.uk), URL http:// } \\
\text { www.casa.ucl.ac.uk/ }\end{array}$ & $\begin{array}{l}\text { paper card with printed } \\
\text { codes }\end{array}$ & $\begin{array}{l}\text { informa- } \\
\text { tional }\end{array}$ & $\begin{array}{l}\text { enable recipient to find } \\
\text { individual }\end{array}$ & $\begin{array}{l}\text { codes linked to postal address } \\
\text { systems, telecommunications and } \\
\text { Internet databases }\end{array}$ \\
\hline $\begin{array}{l}\text { Bank ATM/debit } \\
\text { card }\end{array}$ & person & $\begin{array}{l}\text { card number }(1234 \\
567891234567) \text {, } \\
\text { sort code }(20-55-10) \text {, } \\
\text { account number } \\
(31234567)\end{array}$ & $\begin{array}{l}\text { plastic card with magnetic } \\
\text { strip and gold security } \\
\text { chip on front; codes printed } \\
\text { on the front; name, } \\
\text { expiration dates }\end{array}$ & banking & $\begin{array}{l}\text { swiped in EFTPOS } \\
\text { machine; ATM card reader; } \\
\text { visual inspection to make } \\
\text { payment; entered for card } \\
\text { not present transactions }\end{array}$ & $\begin{array}{l}\text { bank account database with direct } \\
\text { linkage to full personal details } \\
\text { and records of prior transactions; } \\
\text { interbank electronic payment } \\
\text { networks }\end{array}$ \\
\hline Credit card & person & $\begin{array}{l}\text { card number }(1234 \\
567891234567) \\
\text { security code }(7604 \\
111)\end{array}$ & $\begin{array}{l}\text { plastic card with magnetic } \\
\text { strip and gold security } \\
\text { chip on front; codes printed } \\
\text { on the front; name, } \\
\text { expiration dates }\end{array}$ & banking & $\begin{array}{l}\text { swiped in EFTPOS } \\
\text { machine; ATM card reader; } \\
\text { visual inspection to make } \\
\text { payment; entered for card } \\
\text { not present transactions }\end{array}$ & $\begin{array}{l}\text { bank account database with direct } \\
\text { linkage to full personal details } \\
\text { and records of prior transactions; } \\
\text { interbank electronic payment } \\
\text { networks }\end{array}$ \\
\hline Donor card & person & $\begin{array}{l}\text { telephone number } \\
(0123412341234)\end{array}$ & $\begin{array}{l}\text { paper card with printed } \\
\text { codes }\end{array}$ & $\begin{array}{l}\text { informa- } \\
\text { tional }\end{array}$ & $\begin{array}{l}\text { visual inspection of contact } \\
\text { number of next of kin in } \\
\text { the event of death }\end{array}$ & $\begin{array}{l}\text { code links into telecommunica- } \\
\text { tions databases }\end{array}$ \\
\hline $\begin{array}{l}\text { Scrap of yellow } \\
\text { paper with old } \\
\text { password for } \\
\text { university central } \\
\text { computer system }\end{array}$ & person & uccl24! & handwritten on paper & access & $\begin{array}{l}\text { login procedure to network } \\
\text { computer system }\end{array}$ & $\begin{array}{l}\text { authentification database of } \\
\text { computer system; direct linkage } \\
\text { to personal details and records } \\
\text { of prior usage }\end{array}$ \\
\hline
\end{tabular}

computer system 
Table 1 (continued).

\begin{tabular}{|c|c|c|c|c|c|c|}
\hline Item & Type & Codes & Media & Function & Code-reading & Information system or process ${ }^{\mathrm{a}}$ \\
\hline$£ 5$ note & $\begin{array}{l}\text { object, } \\
\text { transaction }\end{array}$ & $\begin{array}{l}\text { HH10907701; } \\
\text { possibly other } \\
\text { hidden security } \\
\text { codes }\end{array}$ & $\begin{array}{l}\text { printed on high-security } \\
\text { paper }\end{array}$ & payment & $\begin{array}{l}\text { visual inspection; machine- } \\
\text { readable by optical-character } \\
\text { recognition }\end{array}$ & $\begin{array}{l}\text { Bank of England databases for } \\
\text { money in circulation; no personal } \\
\text { linkage possible }\end{array}$ \\
\hline $\begin{array}{l}\text { Bromley council } \\
\text { library card }\end{array}$ & person & $\begin{array}{l}\text { A2018200- } \\
5784058 \mathrm{~A}\end{array}$ & $\begin{array}{l}\text { plastic card with printed } \\
\text { barcode; telephone numbers } \\
\text { for different branches }\end{array}$ & access & $\begin{array}{l}\text { visual inspection; scanned } \\
\text { to authorise book } \\
\text { borrowing }\end{array}$ & $\begin{array}{l}\text { library patron database with } \\
\text { direct linkage to personal details } \\
\text { and borrowing history }\end{array}$ \\
\hline $\begin{array}{l}\text { Door access } \\
\text { swipe card for } \\
\text { university }\end{array}$ & person & 3110 & $\begin{array}{l}\text { plastic card with magnetic } \\
\text { strip; visibly printed on } \\
\text { the front; plus telephone } \\
\text { number/fax of card } \\
\text { manufacturer }\end{array}$ & access & swipe-card reader on doors & $\begin{array}{l}\text { local card allocation database } \\
\text { linked to person; provides log } \\
\text { of card usage showing all times } \\
\text { of entry/exits to/from buildings } \\
\text { when card used }\end{array}$ \\
\hline $\begin{array}{l}\text { Staff } \\
\text { photographic } \\
\text { identification } \\
\text { card }\end{array}$ & person & 0282263462 & $\begin{array}{l}\text { plastic card with code for } \\
\text { library on reverse as a } \\
\text { barcode and visibly printed; } \\
\text { name, photograph }\end{array}$ & access & $\begin{array}{l}\text { visual inspection; barcode } \\
\text { scanner for access to } \\
\text { library; barcode reader } \\
\text { to borrow books }\end{array}$ & $\begin{array}{l}\text { library patron database with } \\
\text { direct linkage to personal } \\
\text { details and borrowing history }\end{array}$ \\
\hline $\begin{array}{l}\text { Scrap of yellow } \\
\text { paper giving } \\
\text { various computer } \\
\text { and website } \\
\text { passwords }\end{array}$ & person & $\begin{array}{l}\text { 8-digit alpha- } \\
\text { numeric codes }\end{array}$ & handwritten on paper & access & $\begin{array}{l}\text { login procedures to various } \\
\text { computer, networks systems } \\
\text { and websites }\end{array}$ & $\begin{array}{l}\text { authentication database of } \\
\text { computer system; direct linkage } \\
\text { to personal details and records } \\
\text { of prior usage }\end{array}$ \\
\hline $\begin{array}{l}\text { University of } \\
\text { London Library } \\
\text { borrower card }\end{array}$ & person & 0194335944 & $\begin{array}{l}\text { plastic card with printed } \\
\text { barcode; postal code, } \\
\text { telephone numbers, and } \\
\text { URL for library }\end{array}$ & access & $\begin{array}{l}\text { visual inspection; barcode } \\
\text { scanner for access to } \\
\text { library; barcode reader } \\
\text { to borrow books }\end{array}$ & $\begin{array}{l}\text { library patron database with } \\
\text { direct linkage to personal details } \\
\text { and borrowing history }\end{array}$ \\
\hline $\begin{array}{l}\text { Scrap of paper } \\
\text { with friends' } \\
\text { mobile phone } \\
\text { numbers }\end{array}$ & person & $\begin{array}{l}0781-7811111 \\
0793-9111111 \\
0785-5411111\end{array}$ & handwritten on paper & $\begin{array}{l}\text { communi- } \\
\text { cation }\end{array}$ & make telephone calls & $\begin{array}{l}\text { links into telecommunications } \\
\text { databases; potential linkage } \\
\text { to person }\end{array}$ \\
\hline
\end{tabular}


Table 1 (continued).

\begin{tabular}{|c|c|c|c|c|c|c|}
\hline Item & Type & Codes & Media & Function & Code-reading & Information system or process ${ }^{a}$ \\
\hline $\begin{array}{l}\text { London bus } \\
\text { ticket (route 24) }\end{array}$ & transaction & $\begin{array}{l}427153480917272 \\
\text { (unclear if it is } \\
\text { unique } \\
\text { identification) }\end{array}$ & $\begin{array}{l}\text { slip of paper with printed } \\
\text { code }\end{array}$ & travel & $\begin{array}{l}\text { visual inspection to prove } \\
\text { right to travel with details } \\
\text { of date, time, and fare paid }\end{array}$ & $\begin{array}{l}\text { fare structure and routing of bus } \\
\text { company; no linkage to personally } \\
\text { identifiable capta possible }\end{array}$ \\
\hline $\begin{array}{l}\text { Visa debit } \\
\text { receipt for } \\
\text { Marlborough } \\
\text { Arms, local pub }\end{array}$ & $\begin{array}{l}\text { transaction, } \\
\text { person }\end{array}$ & $\begin{array}{l}\text { card number (1234 } \\
567891234567) ; \\
\text { merchant codes } \\
\text { (M1001004249, } \\
\text { T17239874); } \\
\text { authorisation code } \\
(046256)\end{array}$ & $\begin{array}{l}\text { slip of paper with printed } \\
\text { codes }\end{array}$ & payment & $\begin{array}{l}\text { material record of electronic } \\
\text { transaction, giving date, } \\
\text { time and amount; visual } \\
\text { inspection }\end{array}$ & $\begin{array}{l}\text { bank account database with direct } \\
\text { linkage to full personal details } \\
\text { and records of prior transactions; } \\
\text { interbank electronic payment } \\
\text { networks }\end{array}$ \\
\hline $\begin{array}{l}\text { Receipt from } \\
\text { Boots, chemist } \\
\text { shop (very faded) }\end{array}$ & transaction & not legible & $\begin{array}{l}\text { slip of paper with printed } \\
\text { codes }\end{array}$ & payment & $\begin{array}{l}\text { material record of electronic } \\
\text { transaction, giving date, } \\
\text { time and amount; visual } \\
\text { inspection }\end{array}$ & $\begin{array}{l}\text { bank account database with direct } \\
\text { linkage to full personal details and } \\
\text { records of prior transactions; inter- } \\
\text { bank electronic payment networks }\end{array}$ \\
\hline $\begin{array}{l}\text { Visa debit receipt } \\
\text { from Maplin } \\
\text { Electronics }\end{array}$ & $\begin{array}{l}\text { transaction, } \\
\text { person }\end{array}$ & $\begin{array}{l}\text { card number }(1234 \\
567891234567) ; \\
\text { merchant code } \\
(540436500- \\
392691) ; \\
\text { authorisation code } \\
(0033773) \text {; till } \\
\text { receipt number (R3/ } \\
34878)\end{array}$ & $\begin{array}{l}\text { slip of paper with printed } \\
\text { codes; plus VAT number } \\
\text { of the store, address and } \\
\text { postcode, telephone number }\end{array}$ & payment & $\begin{array}{l}\text { material record of electronic } \\
\text { transaction, giving date, } \\
\text { time, and amount; visual } \\
\text { inspection }\end{array}$ & $\begin{array}{l}\text { bank account database with direct } \\
\text { linkage to full personal details } \\
\text { and records of prior transactions; } \\
\text { interbank electronic payment } \\
\text { networks }\end{array}$ \\
\hline ATM receipt & $\begin{array}{l}\text { transaction, } \\
\text { person }\end{array}$ & $\begin{array}{l}\text { LC3CU51 (ATM } \\
\text { location code) and } \\
004687 \text { (transaction } \\
\text { reference code) }\end{array}$ & $\begin{array}{l}\text { slip of paper with printed } \\
\text { codes }\end{array}$ & payment & $\begin{array}{l}\text { material record of electronic } \\
\text { transaction, giving date, time, } \\
\text { place, and amount; visual } \\
\text { inspection }\end{array}$ & $\begin{array}{l}\text { bank account database with direct } \\
\text { linkage to full personal details and } \\
\text { records of prior transactions; inter- } \\
\text { bank electronic payment networks }\end{array}$ \\
\hline
\end{tabular}


individual product code numbers (for example, car chassis number ${ }^{(4)}$ ) and barcodes that facilitate manufacture, distribution, processing sales, and account management. In this section we examine UPC (Universal Product Code) codes - the common barcodes on groceries - to illustrate the ubiquity of these codes and their utility.

The UPC is undoubtedly the epitome of both the banality and power of identification codes in daily life. Little notice is taken of barcodes, yet they are present on virtually all retail products, manufactured goods, address labels on parcels, and an increasing number of official forms, and it is estimated that some 5 billion barcodes are scanned daily (Thrift, 2004, page 184). Barcodes are ignored primarily because they are not meant for humans, instead they are designed to be read by scanners and processed by information systems, to make physical objects machine-readable. ${ }^{(5)}$ Each barcode has two distinct components: first, an agreed allocation of unique numbers; and, second, the media of parallel black and white printed bars that can be read automatically using a laser scanner (figure 2). The impact of the barcode system has been a reorganisation of retail businesses, transforming inventory control, logistic systems needed for 'just-in-time' operations, and the point of purchase. The first UPC barcode was used on 26 June 1974 in a supermarket in Troy, Ohio, to scan a pack of chewing gum (Morton, 1994). The original concept has been traced back to 1940s with the current UPC standard being developed in the early 1970s by a group of US retailers and food manufacturers, based on a design by IBM (see Brown, 1997; Savir and Laurer, 1975). Their successful development and diffusion was driven, in part, by the replacement of manual tills by new computerised point-of-sales technologies, so that, by April 1976, some 75\% of goods in US supermarkets had a UPC barcode (Dunlop and Rivkin, 1997).

UPC barcodes printed on consumer goods are the most common form, but there are in fact a wide range of different systems, with a diversity of printed symbol styles deployed for different application areas and industries, including the Code 128 format barcode used in the title of this paper (see Harmon, 1994; Palmer, 1995). Many large organisations and industrial sectors have developed their own particular form of barcode representation and protocols for allocating numbers.

The barcode system provides only a single identification code number, the rest of the details describing the object (for example, product type, date of manufacture, price, etc) have to be held in an information system. In this way the true importance of barcodes is that they provide a very cheap, simple, unambiguous, and reliable 'digital thumbprint' that can be placed on almost any object and consistently read back by a computer. Barcodes link material things to their virtual representation, making them machine-readable. Barcodes provide an easily distributable means of identification vital to maintaining distanciated, global supply chains. Hosoya and Schaefer (2001, page 157) thus describe them as the 'bit structures' that organise and synchronise flows, acting as "the mechanism by which the virtual establishes its logic in the real". Further they provide a means, when accompanied by loyalty cards, of tracking consumer tastes and undertaking target marketing. As we detail below, the strengths of the barcode (simplicity and lack of granularity) are also its major weakness and, as a result, barcodes are being replaced by new coding systems held by smart labels and tags (that have a finer resolution and can hold more capta).

(4) This is the 17-digit Vehicle Identification Number, a global standard defined by ISO 3779 in 1983 (http://www.vehicleidentificationnumber.com/).

(5) The actual numbers written underneath barcodes on consumer products are for the convenience of humans and are not read by the scanner. 


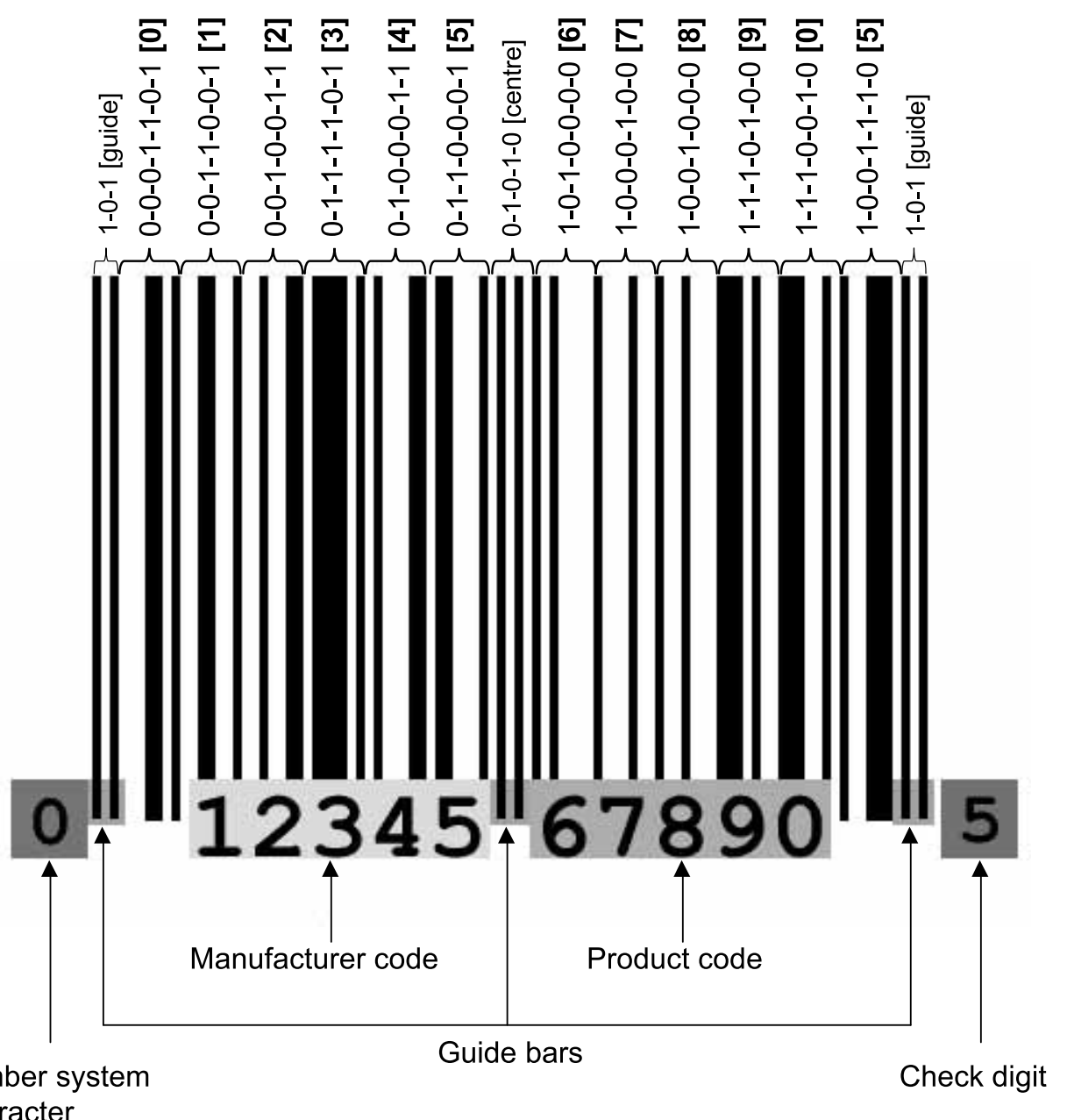

Number system character

Figure 2. Decoding the barcode. Shown is a 12-digit UPC (Universal Product Code) barcode used in the United States and managed by the Uniform Code Council. The barcode media stores the number 012345678905 , with each digit encoded in binary form by a unique sequence of seven black bars (1) and white spaces (0). The number 3, for example, is represented by the sequence: space - bar-bar-bar-bar-space-bar (0111101). The binary representation on the left-hand and right-hand sides are inverses of each other, so the barcode can be scanned unambiguously from either direction.

\section{Information codes}

Moving beyond physical objects, there has been a move to generating capta related to information (text, sound, image, or video). Conventionally, industry-specific identification systems have developed to be focused around the particular media format that information is usually stored and distributed on, such as ISBNs for books, ISSNs for periodicals (the one for Society and Space being 02637758, which is represented as a barcode on the back cover of the printed issue), and ISWC for music. ${ }^{(6)}$ These codes are often inscribed on the

(6) The ISBN (International Standard Book Number) system began in 1966 and was adopted as international standard ISO 2108 in 1970 (http://www.isbn-international.org/). ISSN (International Standard Serial Number) was designated in 1974 and is managed by a worldwide network of 77 National Centres and an International Centre based in Paris (http://www.issn.org/). ISWC (International Standard Musical Works Code), defined by ISO 15707 in 2001, is managed by the International Confederation of Societies of Authors and Composers (http://www.iswc.org/). 
physical media through barcodes. Many of these identification code numbers are developed and operated as necessary supports for the intellectual-property regimes of publishers.

The rapid shift of information production to digital formats, most particularly in terms of Internet content in the 1990s, has spurred the development of many new schemes of identification and metadata. The rapid take-off of the Web in the mid-1990s can be put down, in part, to its simple but effective identification scheme of URLs (uniform resource locators). This is a distributed scheme that enables anyone to specify a globally unique identifier and network location of their homepage. However, a significant limitation with URLs is their lack of persistence-giving rise to the problem of broken Web hyperlinks - as a result of the failure to separate location from identity in the scheme. One attempt to solve this, which has found particular favour with libraries and academic publishers that require a high degree of permanence, is the DOI (digital object identifier) scheme. This allows information publishers to assign a unique identifier (for example, Pion has assigned this paper a DOI listed above the title) that never changes and lets the actual location of the information be stored separately. The DOI system was developed in the late 1990 s and is operated by the International DOI Foundation (http://www.doi.org) (Paskin, 2003). It is a distributed system (so publishers can use their own identification scheme for items they 'own') and is also compatible with existing Web software and URLs.

The growth in sharing of digital information (especially the use of the MP3 format for music) is forcing media corporations to develop new identification code systems for enforcing control of the distribution and use of content. These codes will identify each individual instance of a piece of music and be tied to individual customers. As such, codes are at the heart of 'digital rights management' and will be key in future intellectual property 'wars' (Lessig, 2004).

\section{Transaction codes}

Many transactions in everyday life, particularly those involving communication and money of some kind, are also made machine-readable through the application of identification codes. These are usually generated automatically, often comprising some combination of exact time, location, and nature of the transactions. Transaction identification codes serve especially as a means of authentication and are readily apparent on banal objects such as receipts and tickets (table 1). Indeed, in some circumstances, such as air travel, the physical ticket is being replaced by e-tickets, which are simply transaction identification codes sans media (see Dodge and Kitchin, 2004). Importantly, the assignment of unique identification codes for the many transactions which are ephemeral processes and leave no physical trace of their happening (for example, a telephone call) provides a lasting record that is used for billing, statistical monitoring, or in the event of future queries. The identification code is usually required to link a transaction to a particular person and/or place and time.

To a large extent money has become an electronic transaction, with vast flows at the global scale in terms of trading on financial markets, and more locally through retail banking. The growth in business-to-business transactions on electronic data interchange (EDI) networks, and in flows on electronic funds transfer (EFT) networks and, more recently, online via the Internet, has spurred on the development of many important forms of transaction identification. EFT networks now interconnect millions of ATMs and point-of-sales terminals at retailers. It is impossible to quantify reliably the range of identification codes, and total transaction volumes, used in these movements of money across the world but it is in the order of billions a day. For example, in the USA in 2002 there were an estimated 19028 million PIN-based 
payment transactions (13968 million at ATMs and 5060 million at point-of-sales terminals), up from 7495 million transactions in 1992 (ATM and Debit News, 2003, page 2). In Britain there were 4.7 billion payment transactions made with debit and credit cards in 2002, amounting to some $£ 211$ billion, an average of $£ 86$ per adult per week (APACS, 2003).

Information exchange over telecommunications networks also generates huge daily volumes of transaction capta, as each message is uniquely coded to insure successful transmission. Much of this identification coding is automated and unseen by sender or receiver; for example, all Internet e-mail is given a unique identification upon despatch which is contained in the header information (this is not visible by default in most e-mailreading software). A typical example, is 5.1.0.14.0.20040202131004.036c2378@Mail.may.ie taken from an e-mail between Dodge and Kitchin, created by the Maynooth mail server. To illustrate further the range of transaction identification codes in telecommunications, table 2 provides an audit of codes used in a typical online interaction. To enact this transaction, at least fifteen different unique identification codes are used, some of which are person identifiers and others of which are assigned automatically by software in various parts of the assemblage for the length of the transaction. As a consequence, accessing a bank account online generates much more capta than a face-to-face transaction in a branch.

Table 2. The identification codes involved in an online transaction using an Internet banking service (dial-up home access).

1. Login to computer. Person identification codes: username, password.

2. Establish dial-up Internet connection via telephone provider. Person identification codes: telephone number, username, password.

3. Caller line identification number identifies the dialling source location and is automatically logged in telephone network system, primarily for billing purposes.

4. Internet access is authenticated by the ISP using RADIUS protocol. Transaction codes: unique session identifier code set, PC is assigned Internet Protocol address. Details on these code assignments are logged by ISP for billing and account usage monitoring.

5. Open Web browser, enter domain name and load the bank's homepage. Transaction codes: assigned permanent and session 'cookies' by the bank Web server.

Permanent cookie: e-mail.barclays.co.uk FALSE/FALSE 1753985730 ssuserid v2.1060167458.639.62.7.132.29.595.wwwll; session cookie: www.personal.barclays.co.uk FALSE/FALSE 2006273884 brcvisitor 1060167612227269483371107091.

6. Click on hyperlink to secure Internet banking section of the website. Transaction codes: another cookie set, 128-bit Secure Sockets Layer certificate to encrypt communication is exchanged.

7. First part of the login and authentication process for Internet banking. Person identification: surname, 12-digit Internet banking membership number.

8. Second part of the process. Person identification: 5-digit passcode, 2 letters randomly chosen from your memorable word. Details on verification process are logged by bank.

\section{Territorial codes}

Spatial identification codes are systems that locate people, places, and objects across the terrain of the globe. Such spatial identification systems, in a UK context, are detailed in figure 3 (see over) and include latitude and longitude, grid references, and administrative units such as postcodes. These systems vary in their scale and resolution (granularity) but they all work to standardise continuous, ongoing spatial relations into fixed, knowable territorial units by generating unique locational capta. Particularly apposite historical examples of this spatial standardisation are the large-scale topographic surveys of the Enlightenment and Victorian eras, especially in colonial contexts [for example, the survey of India (Edney, 1997), and of the USA (Johnson, 1976)], focused on capturing 


\section{Digimap $p^{\circ}$

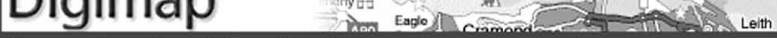

Search summary

You searched for a 'start' match on 'badgers mount'

Download results

Set format $\quad \longdiv { T e x t ( \operatorname { c s v } ) \nabla }$ Set number of results $\longdiv { 1 \quad \nabla } \quad \square$ Download

Search results

Results 1 to 1 of 1

Badgers Mount

Search took 0.001 seconds

Attributes

$\begin{array}{ll}\text { Entry Number } & 11891 \\ \text { National Grid 1 km Square } & \text { TQ4962 } \\ \text { Place Name } & \text { Badgers Mount } \\ \text { Latitude degrees } & 51 \\ \text { Latitude minutes } & 20.5 \\ \text { Longitude degrees } & 0 \\ \text { Longitude minutes } & 8.8 \\ \text { National Grid Easting } & 549500 \\ \text { National Grid Northing } & 162500 \\ \text { East or West of Greenwich } & \text { E } \\ \text { County Code } & \mathrm{KT} \\ \text { Abbreviated County Name } & \text { Kent } \\ \text { Feature Code } & 0 \\ \text { Entry Date } & 01-\mathrm{mar}-1993 \\ \text { Council Code } & \text { I } \\ \text { Landranger Map Sheet 1 } & 177 \\ \text { Landranger Map Sheet 2 } & 188 \\ \text { Landranger Map Sheet } 3 & 0 \\ \text { County Name } & \text { Kent } \\ \text { Feature Type (derived) } & \text { Other settlement }\end{array}$

(9) University of Edinburgh.

Figure 3. A range of territorial identification codes generated for places in the United Kingdom from the Ordnance Survey's 1:50 000 gazetteer (source: Digimap Gazetteer Plus, EDINA digital library service, University of Edinburgh, http://www.edina.ac.uk).

all geographic knowledge deemed important to the government. As such, territorial identification codes have long been used to manage both populations and businesses, with governments, in particular, creating systems with regards to collecting capta, identifying and classifying land use, and providing services (for example, registration of land or property ownership, collection of taxes, the election of officials, delivery of mail) [see Thrift's (2004) analysis of the 'knowledges of position']. These systems have been adopted by other organisations as a means to deliver services.

The drive towards totalising spatial knowledge at finer scales is clearly evident in the development of many national digital geospatial infrastructures across different 
countries in the last decade (Rhind, 1997). The development in the United Kingdom of the National Land and Property Gazetteer (NLPG) and the Ordnance Survey's (OS) Digital National Framework, known commercially as MasterMap, has given rise to new systems of highly detailed territorial identification coding. The NLPG is a digital cadastre which assigns 8-digit 'unique property reference numbers' (UPRNs) to all property entities ${ }^{(7)}$ and the OS MasterMap goes further to assign 16-digit numeric 'topographic identifiers' (TOIDs) to all significant mapped natural and man-made features (as defined by the formal rules and everyday practices of the OS surveyors who produce the underlying spatial capta). The promotional rhetoric for these two examples of intensified territorial identification coding speaks to the increased versatility, functionality, and efficiency, as they become "common hooks held on any number of databases within and between different organisations" (Triglav, 2002, page 12), and an OS marketing piece "Joined-up geography" notes, "Like barcodes on products, TOIDs given to landscape features provide more intelligence for the relevant user" (PCSA, 2002, page 182). As of summer 2003 there were some 448 million TOIDs assigned, ${ }^{(8)}$ a raw metric of the extent of the standardised British landscape capta, the available record of geographic reality that can be uniquely addressed and 'worked' directly by software.

Traditionally the power of territorial identification codes has been that they tie people and objects to particular addressable units, allowing them to be located, tracked, and managed, consistently; more recently that power has been magnified by four developments. First, more and more capta are being tied to spatial referents, with this being greatly enhanced by the use of relational databases that share common fields and can be matched to other databases. Second, the granularity of much spatial capta has been increased, with data being increasingly tied to finer spatial resolutions - for example, individual households and land parcels as opposed to neighbourhoods or routine use of submetre coordinates from satellite global positioning systems (GPS). Third, static snapshot capta trails of transaction-generated data (for example, the location of credit card purchases) are gradually being replaced by dynamic data trails gathered by technologies that actively and continuously track spatial location by using GPS and radio location. Fourth, there is a marked increase in the ability to spatially analyse, model, and simulate territorial capta, as evidenced in the adoption of geographic information systems (GIS) in many organisations.

\section{Towards the fully machine-readable world}

At present, personal, object, information, transaction, and territorial codes provide a series of oligopticons - that is, segments of much larger capta shadows. The growing pervasiveness of identification codes and informational systems that match, trace, monitor, and regulate populations, however, works to transform the various oligopticons into one universal panopticon: a dense rhizomic assemblage that will enable its users to know simultaneously and in real time the what, when, and where of people and things; to make all of Solzhenitsyn's thread visible and usable. Here, we use the phrase 'rhizomic assemblage' rather than, say, 'grid' because we want to acknowledge that the capta fields are complexly interlinked and are not uniform, varying as a function of granularity, scale, and context.

The nature of this spatialised rhizomic assemblage is, we contend, in a process of transformation as a result of four recent trends: the drive towards generating capta wherever and whenever possible; the drive towards far finer capta granularity; extended

(7) The UPRN itself is just part of a much larger British Standard BS 7666 (spatial datasets for geographical referencing).

${ }^{(8)}$ Source: e-mail communication (28 August 2003) to R Hodgson, Marketing Manager, OS MasterMap Strategy and Delivery. 
storage of capta shadows; and enhanced means of processing and analysing capta. These trends, each of which we discuss below, coalesce as a metatrend, that of the creation of a machine-readable world. The undeclared logic of the machine-readable world is 'all data, all the time, on all people, at all places', where risk is eliminated through perfect knowledge (see also Lianos and Douglas, 2000).

\section{Voracious capta generation}

There is presently a trend towards massively increasing capta generation, which seems to be driven partially by a 'collect-it-if-you-can' mentality and partially by a belief that increased volumes of key capta will provide enhanced marketing, competitive advantage, safety, security, and so on. These discourses have been accompanied by the process of 'control creep', "whereby the social control apparatus progressively expands and penetrates (or 'creeps') into different social arenas, in response to a set of inchoate fears about a sense of security in late-modernity" (Innes, 2001). 'Control creep' can perhaps be best seen in action surrounding intensification of air-travel security with the rise of aggressive passenger profiling and biometric authentication (Lyon, 2003b). Post-9/11 securitisation also provides reasoning that allows existing administrative identification and record-keeping infrastructures to be remodeled as part of generalised 'antiterror' surveillance and riskreduction apparatus (for example, the use of the London Congestion Charge system, with its network of automatic number-plate recognition cameras, as a security screen). As we explore elsewhere, this clearly has implications for issues of privacy and confidentiality, hence the proliferation of data-protection and freedom-of-information laws (although these are increasingly under threat). The transference from 'dumb' to 'smart' technologies, and to dynamic and mobile tracking, is an aspect of the desire to generate as much capta as possible, taking advantage of the development of new technologies.

\section{Dumb to smart}

"The telescreen received and transmitted simultaneously... . There was of course no way of knowing whether you were being watched at any given moment."

Orwell (1987 [1949], page 4)

Many of the material objects and environments used in everyday life are shifting from dumb to smart and in the process becoming capable of creating significant new streams of personally identifiable capta. In this context, smart means programmed awareness of use, rather than intelligence. So household objects (for example, televisions, VCRs, cameras), cars, and spaces are, through the application of sensors and software, being made aware of how they are being used (for example, time, location) and, crucially, which people use them. This awareness of usage is easily captured as logs and transmittable to third parties (especially through wireless technologies such as Bluetooth). In the last decade or so there has been burgeoning interest in so-called ubiquitous computing, reactive environments, and 'smart' objects, but it is only relatively recently that widespread deployment has been occurring, as part of a more generalised 'automatic production of space' (Thrift and French, 2002).

Importantly, in the shift from dumb to smart the overt nature of these objects and environments does not change - they still look the same, operate in much the same way, and give the same results (although often with enhanced features). The capta-enabling software is invisible to users. The smartening of the things is widely trumpeted in terms of increased consumer convenience, but more insidiously there is no doubt that it is opening new conduits for surveillance of individual activity patterns. Home entertainment appliances, particularly televisions and VCRs, provide good exemplars of 'smart' appliances. The newest interactive televisions and digital VCRs look similar to their 'dumb' forebears, but the addition of software and network feedback means they are able to 'watch' the 
viewers watching them. By 'watching' we mean they are aware of the behaviour of users and can transmit this back to the service provider. ${ }^{(9)}$ The mundane nature of television, easy to use and freely available in almost every household, belies the degree to which viewing preferences reveal inner thoughts and the value which media corporations place on obtaining a direct feed on these kinds of capta. Smart entertainment appliances are also likely to become cornerstones, along with personalised identification codes (digital certificates) on media objects, in new regimes of 'digital rights management' (DRM). In the DRM future envisaged by large media corporations, the interlocking of 'hard' identification systems on both the entertainment content and playback equipment, creating a secure 'content control system', is seen as vital to continued growth in revenue. A potential scenario of the future is that a customer will buy a license to watch a given film, playable only on his or her television for a fixed length of time (and will quite likely include targeted advertising that cannot be skipped), all made possible by specific codes for identification and authorisation. It should be noted, however, that there is active resistance to attempts at this new cultural 'enclosure' by big business, particularly from consumer rights and open-source software activists.

The car is another prime example of an environment that is rapidly shifting from 'dumb' to 'smart'. As Thrift (2002, page 10) notes, "Almost every element of the modern automobile is either shadowed by software or software has become...t the pivotal component." Although the car still appears the same and drives in the same fashion, its systems are increasingly aware of their performance through onboard diagnostics, its location through GPS-tracking, and the actions of the driver. The result is that cars are now rich capta generators, logged in event data recorders hidden from view but recallable. ${ }^{(10)}$ The implications of smart cars are only just being felt, with capta being used in accident court cases and 'spy' scare stories in the press (for example, Austen, 2003). As Elliot (2004) reports, the GPS navigation systems such as Hertz's NeverLost were initially intended to help motorists find their way; however, more recently, they have been used to catch renters who drive out of state or break speed laws. Longer term, the implications of smart cars are likely to have much more of an effect on driving behaviour, as the combination of telematic streets and in-car capta on drivers will potentially enable new regimes of variable road pricing and 'flexible' insurance rates calculated on a journey-by-journey basis.

\section{Always on}

Conventionally, the capta shadow consists of a limited snapshot revealing person or object actions at particular known times. In most cases capta generation is usually triggered by a transaction of some kind (for example, purchase by a credit card, entry into a country by passport). Increasingly, however, the ability to generate continuously capta about people and objects in real time is being realised. For example, the performance of a worker in a supermarket checkout is continuously recorded in order to monitor worker performance. Similarly, Web-browsing patterns can be recorded in great detail-so-called 'click-stream' surveillance - by using cookies and other transaction identification codes (table 2; see also Bennett, 2001). Turning off cookies (and their surveillance) seriously degrades the functionality of a large part of the Web. Here, the technology of unique identification that enables both parties to perform their tasks

(9) A telling example is the tracking of viewing habits during the 2004 Super Bowl by TiVo digital VCRs, which revealed the popularity of Janet Jackson's 'wardrobe malfunction'. See, for example, "TiVo: Jackson stunt most replayed moment ever", CNN 3 February 2004, http://www.cnn.com/ 2004/TECH/ptech/02/03/television.tivo.reut/index.html.

(10) This is analogous to the 'black box' flight data recorders which have been mandatory in all aircraft for many years. 
is also the means of surveillance. In effect, this is a form of 'casual surveillance' that largely goes unnoticed and unchallenged because it seems to be inherently part of the technology. Moreover, systems are often set to gather excessive amounts of personal data, with default settings rigged so that people have to choose consciously to 'opt out'. In addition, systems are promoted in ways that encourage people to adopt, with penalties such as the degradation of service, or additional costs (in time or money), or service denial. This promotion becomes more compulsory in nature where the controlling organisation has significantly more power in the transaction than the individual-for example, in a monopoly situation such as welfare payments (see Gilliom, 2001).

\section{Mobile}

In conventional databases only a rudimentary capta trail can be constructed for a person or object by mapping the time, date, and location of each transaction. The movements in between the point of direct identifiable transactions remain unknown. However, these spatial gaps are being filled through the employment of embedded, cheap, and accurate, always-on GPS and radio tracking systems. In the case of wireless information and communication technologies, particularly mobile phones, the location of all new devices can be continuously monitored by network companies, even if the device itself is switched off from the users' point of view. In effect, the network operating companies know to within a few hundred metres everywhere a person's telephone has been, and by implication the person. In other words, a complete capta trail is revealed. Such continuous spatial tracking will become commonplace in the next few years, encouraged in large part by the development of novel location-based services (LBS). In essence, LBS is about providing individualised information based on people's geographic location and it is highly likely that such data will be automatically logged and become part of the capta shadow. Clearly, being able to track people and objects spatially in real time has significant implications with regards to individual privacy as the spatial gaps in the oligoptic capta shadow disappear (see for example, Phillips, 2003). Consequently, Dobson and Fisher (2003) have argued this trend may lead to geoslavery for some.

\section{Increased granularity}

Many of the discourses surrounding identification codes intersect in contemporary Western society in technological drives to eliminate the fallibilities of many existing analogue forms of identification by increasing the granularity of identification. Here, we consider two illustrative examples: biometrics and smart labels.

Personal identification - in the passport, for example - has traditionally consisted of printed matter, whether that be text or photographs. The problem with some means of documentary identification is that they are open to forgery or doctoring. With technical advancements, these forms of fallible identification are in the process of being replaced by unique biometric forms that are extremely difficult to fake. They promise a technical fix to what are often more complex social issues (for example, the pressure of underage drinking which drives the market for fake identification). Biometric identification systems seek to render people machine-readable, and by "fusing together flesh and machine" (Davies, 1994, page 38) they enforce the infallible linkages of individuals to their records in information systems. ${ }^{(11)}$ At present, the most well-known biometrics utilise distinctive physiological patterns on fingertips and the eyeball, but the 'ultimate' biometric is 'hidden' internally in the patterning of DNA. Here, the fingers, eyes, and genes are the physical media carrying unique

(11) In fact, biometrics are not as infallible as is widely claimed: see, for example, Lander's (1992) detailed analysis of the weaknesses in DNA evidence. 
biological codes (for example, the loops, arches, and whorls of skin on the fingertip) that are scanned in some form to produce digitised capta suitable for storage and processing by software. The computer does not store the fingerprint per se, but stores a unique numerical code representation of it. This code is a digital biometric which can then be automatically verified against other documentary identification (at some set threshold of reliability), usually for purposes of authentication. In some instances several different types of biometric are taken to increase the effectiveness of identification.

These biometric forms of identification seek to fulfil Clarke's (1994b) list of desirable characteristics for effective human identification codes:

(1) universality of coverage (everyone should have one);

(2) uniqueness (each person should have only one, and no two people should have the same one);

(3) permanence (should not change, nor be changeable);

(4) indispensability (a natural characteristic that cannot be removed);

(5) collectibility;

(6) storability;

(7) exclusivity;

(8) precision;

(9) simplicity;

(10) cost and convenience;

(11) acceptability.

Until now, biometrics have performed well on criteria one to four, because they are naturally available, globally unique, and cannot be lost or easily faked. However, biometrics have not been widely deployed for routine identification thus far because they have traditionally performed poorly in terms of criteria five through eleven. For example, ink fingerprinting has been costly, inconvenient, hard to store and process, and deemed socially unacceptable because of its stigmatisation through criminal associations. Consequently, biometric use could be justified only in special circumstances, such as controlled access to high-security facilities. In the last five years or so, technological changes in terms of noninvasive, cost-effective capture of biometrics (for example, hand geometry scanning) and ease of digital storing and processing have made it much easier to deploy; consequently, use has been growing - for example in workplace time and attendance systems to prevent 'buddy-punching' fraud. The dramatic upsurge in securitisation post-9/11 has focused extensively on the 'need' to deploy biometrics, with many states moving to include biometrics on passports and national identification cards because of the concern that visual face-to-passport verification by immigration officials at borders is insufficient. Increased investment in the development and deployment of biometric identification to automate video surveillance is also likely to continue, in spite of the substantial technical failures of current facial-recognition software in practice (Gates, 2002; Meek, 2002).

Another example of the trend of finer granularity is 'smart labels'. As noted earlier, barcodes are limited because of their level of granularity. All objects of the same product possess the same barcode, meaning that they cannot be discriminated. As a result, in recent years, considerable effort has been placed on developing 'smart labels' with increased granularity which enable individual object recognition. This increased granularity is on the one hand to increase the ability to track individual items (to reduce and track theft), and on the other to provide greater personal surveillance. One obvious extension is $2 \mathrm{D}$ barcodes which encode data both horizontally and vertically in a block of speckled of dots, so are able to store unique capta (an example is the encrypted PDF417 format barcodes used on the majority of US drivers' licenses). The US Postal Service plan for I-Mail (intelligent mail) and Royal Mail's 


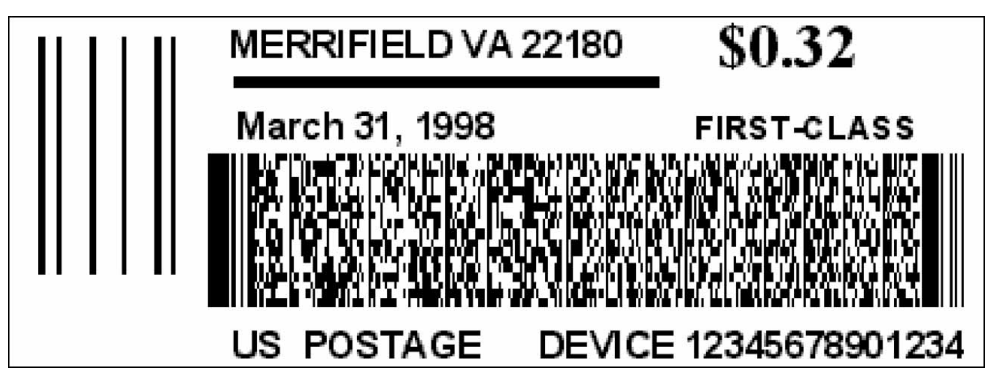

Figure 4. PDF417, an example of a high-capacity 2D barcode. It is used here in a design for the US Postal Service's proposed new personalised, secure postage stamp (source: http://www.symbol.com).

introduction of 'SmartStamps' both use 2D barcodes as a form of personalised stamp (figure 4) that identifies the sender in terms of the person and their location (plus other information such as billing details). This it is hoped will improve the efficiency of tracking mail through the sorting and delivery system, while simultaneously improving surveillance of the sendee. ${ }^{(12)}$

At their simplest, 'smart labels' such as 2D barcodes are really extensions of existing systems of object identification except that they hold more data, but more sophisticated technologies such as RFID (Radio Frequency Identification) tags represent and communicate the code quite differently. The goal is to provide objects with some level of 'awareness' and an ability to communicate over short distance using wireless networking technologies (Want et al, 1999).

RFID tags aim to provide a means to 'identify any object anywhere automatically'. They are small chips composed of a simple digital circuit and an antenna that are embedded with a unique identification code and can be read at a distance by a radio transponder, rather than having to be passed in line of sight of a laser scanner. They are presently most widely used in vehicle dashboard tags for automatic toll payment (the main system in the USA being EZPASS) and in livestock to facilitate "farm-to-fork traceability" with growing concerns over food safety (Wired News 2003). Their main application though is likely to be in retail where they are seen as a major advance in inventory management and the fight against shoplifting (Ferguson, 2002).

In terms of the identification codes stored by the RFID chip the leading standard is known as the Electronic Product Code (EPC) developed by the Auto-ID Center, an industry-sponsored $\mathrm{R} \& \mathrm{D}$ lab at Massachusetts Institute of Technology, and now being actively commercially implemented by EPCglobal Inc. (a joint venture of the Uniform Code Council and EAN International, the main players in UPC barcode management). The definition of the EPCs creates a truly huge number space, enough to identify uniquely every object on the planet (figure 5).

RFIDs chips and their EPCs work as part of a global information network which provides the means to 'lookup' details automatically on any tagged object from any location (with an Internet connection). Borrowing the domain-name schema used on the Internet, the EPC network will use a distributed Object Naming Service (ONS) to link each EPC number to the appropriate naming authority database that provides the detailed information. ${ }^{(13)}$ The goal, as articulated by Kevin Ashton, a Proctor \& Gamble executive who headed the Auto-ID Center, is " ... an internet for things, a standardized way for computers

(12) The I-Mail system is still in the consulting stage, but under the proposed system mail that lacks a personalised 2D barcode would be subject to much more rigorous screening for hazardous contents. (13) The contract to operate the ONS lookup element of the EPC Network was awarded to VeriSign in January 2004. VeriSign is the controversial US corporation that operates major elements of the Internet domain-name system. 


\section{Q1.0000AB9.000lbF.000lЬ9DCD \\ Header 8-bits

\author{
EPC Manager \\ 28-bits
} \\ Object Class \\ 24 -bits \\ Serial Number 36 -bits}

Figure 5. The structure of a 96-bit EPC (Electronic Product Code), partitioned into four parts to allow flexibility in object identification RFID (Radio Frequency Identification) tags. The header defines the type of EPC. The 28-bit manager element allows for 268435455 different users (typically product manufacturers), who are able to define uniquely 16777215 different types of object. Each of these is then assigned a 36-bit serial number, giving a total of 68719476735 potential unique identification numbers per object type. In total the EPC-96 number space can uniquely identify $3^{26}$ different entities (source: Technology Guide, Auto-ID Centre, 2002; http://www.autoidcenter.org).

to understand the real world" (Schoenberger, 2002). Importantly, the querying of the ONS as RFID tagged products move through supply chains will automatically create a richly detailed audit trail of capta, identifying everyone who handles the goods. Further, these capta trails will be geocoded as the location of fixed RFID readers will be known. The result will be a much greater degree of routine 'machine-to-machine' generated knowledge on the positioning of many millions of physical objects in time and space. Aggregated patterns of these RFID-generated capta trails will give an unprecedentedly detailed view of the material flows of products across space, a newly revealed microeconomic geography of the machine-readable world.

Evangelists for RFID tagging and the EPC network envisage a wide range of innovations in the handling of physical objects arising from these networked capta trails (see Ferguson, 2002, for typical speculation). Inside stores, the 'holy grail' is so-called 'smart-shelving' that is aware of its own stock levels and the activities of individual customers. In the home pundits are talking of microwave ovens checking the best cooking settings for ready meals, washing machines choosing the most appropriate cycle for clothing, and medicine cabinets able to 'spot' out-of-date or recalled pharmaceuticals. There could also be potential for tracking goods at the end of the life cycle, alerting bin men to items containing toxic substances for example. There are also many privacy concerns, but discussion of these is beyond the scope of this paper.

\section{Forever storage}

The capability to log, process, and permanently store capta shadows has become feasible for most businesses and organisations as the real cost of computer storage has plummeted in the last decade. Developments in hard-disk technologies, in particular, have relentlessly pushed up the capacity and thus driven down the cost per megabyte of data storage, making it considerably cheaper than paper or film (Grochowski and Halem, 2003). Gilheany (2000) has estimated that, since the introduction of the first commercial magnetic disk storage by IBM in 1956, the cost per gigabyte has fallen by a factor of a million to one. The growth in storage density, as measured in bits per inch on magnetic disks, has even outpaced the curve of Moore's Law ${ }^{(14)}$ and shows little signs of slowing down in the near future. The actual physical space required for data storage has also shrunk dramatically, as hard drives have got smaller and the density of packing increased. This growth in storage capabilities enables radically different strategies of information management with the deleting of old files virtually unnecessary. The cost barriers to storing large parts of people's capta shadows over an entire life course have thus been erased. (15) As a result, transactions

(14) See http://www.intel.com/technology/mooreslaw/index.htm.

(15) This is not to underestimate the significant practical difficulties of long-term digital data preservation (Lazinger, 2001). There are technical issues of fidelity in storage media and format of the content, as well as wider issues concerning authentication, intellectual-property rights, and institutional cultures. 
undertaken today (for example, a message sent to an e-mail list, paying in a store with a credit card, speaking to a friend on the telephone) may well be logged and kept beyond the death of the person, with the potential to be recalled and analysed at any point in the future. ${ }^{(16)}$ In addition, many more dimensions of daily life are being logged and stored simply because the cost of doing so is marginal. Such long-term retention is driven on the governmental side for security and surveillance purposes and on the business side for its present commercial value, or likely future potential value.

\section{Enhanced capta processing and analysis}

The preceding trends primarily focused on changes in the production of key capta. In this section we detail two related trends that alter capta processing and use.

\section{Convergence}

The enormous growth in databases means that tables with shared fields can be easily matched and compared. (17) At present, there is a drive towards marrying relational databases as the convergence allows more of the capta shadow of an individual or object to be revealed. As such, this convergence means that previously unknown relationships between capta become visible. This is particularly the case given the vast amounts of capta generated for each individual, entity, and transaction. Moreover, this convergence facilitates the widening and deepening of geographical coverage as more and more capta are tied to spatial referents, and as territorial capta becomes more widespread with increased granularity. A good example of the exploitation of convergence are the various personal data aggregators and resellers such as US Search and ChoicePoint, which allow consumers to 'pull together' vast amounts of capta from related databases to profile individuals (including social security, health, education, court, criminal, property records; and to screen contractors, nannies, neighbours, and so on) through a simple Web interface. The big three US credit reference agencies, Equifax, Experian, and TransUnion, have also been joined by a number of other lower profile data consolidators, such as Acxiom, Innovis, and Seisint, who are involved in developing predictive models of individual behaviour.

\section{Precise, predictive profiling}

Huge volumes of capta are presently accumulating, particularly from transactiongenerated data, in information systems that are then being 'data mined' to exploit their latent value. Data mining or 'knowledge discovery from databases' (KDD), consists of a set of exploratory analytical techniques (see table 3) premised on the "belief that information is hidden in very large databases in the form of interesting patterns. These are non-random properties and relationships that are valid, novel, useful and ultimately understandable" (Miller and Han, 2001, page 4). The goal of KDD is a better understanding of people's behaviours through the analysis of what they do, resulting in evermore precise profiles. As such, KDD analysis is used by commercial organisations, particularly retail and fraud detection in financial services, and increasingly in the realm of policing. The use of predictive profiling particularly affects life chances of millions in terms of credit-scoring (Leyshon and Thrift, 1999) and can be used as a filter to channel particular goods, services, information, opportunities, and life chances to some people and not others. Businesses view KDD as a way to focus on their 'high lifetime value customers' and to exclude the other segments of customers (these might

(16) There are, of course, still major technical challenges in the intelligent summarisation and analysis of such huge and detailed terabyte databases.

(17) Indeed, the potential of matching records in disparate 'data banks' has been an enduring fear 
Table 3. Key data-mining techniques (source: Miller and Han, 2001, page 8).

\begin{tabular}{|c|c|c|}
\hline Data-mining task & Description & Techniques \\
\hline Segmentation & $\begin{array}{l}\text { Clustering: determining a finite set of } \\
\text { implicit classes that describes the data } \\
\text { Classification: mapping data items into } \\
\text { predefined classes }\end{array}$ & $\begin{array}{l}\text { Cluster analysis } \\
\text { Bayesian classification } \\
\text { Decision or classification trees } \\
\text { Artificial neural networks }\end{array}$ \\
\hline Dependency analysis & $\begin{array}{l}\text { Finding rules to predict the value of some } \\
\text { attribute based on the value of other } \\
\text { attributes }\end{array}$ & $\begin{array}{l}\text { Bayesian networks } \\
\text { Association rules }\end{array}$ \\
\hline $\begin{array}{l}\text { Deviation and outlier } \\
\text { analysis }\end{array}$ & $\begin{array}{l}\text { Finding data items that exhibit unusual } \\
\text { deviations from expectations }\end{array}$ & $\begin{array}{l}\text { Cluster and other data-mining } \\
\text { methods } \\
\text { Outlier detection }\end{array}$ \\
\hline Trend detection & $\begin{array}{l}\text { Lines and curves summarising the } \\
\text { database, often over time }\end{array}$ & $\begin{array}{l}\text { Regression } \\
\text { Sequential pattern extraction }\end{array}$ \\
\hline $\begin{array}{l}\text { Generalisation and } \\
\text { characterisation }\end{array}$ & Compact descriptions of the data & $\begin{array}{l}\text { Summary rules } \\
\text { Attribute-oriented induction }\end{array}$ \\
\hline
\end{tabular}

not even be unprofitable, simply not profitable enough) (see analysis by Danna and Gandy, 2002; Graham, 2004).

Closely allied to KDD are geodemographic profiling and geoprocessing founded on GIS. The GIS industry is centred largely on the aggressive acquisition and exploitation of territorial capta, creating systems able to enact evermore realistic models of 'geographic reality'. The combination of GIS and much greater amounts of social capta on large numbers of people (in some cases whole populations) is proving irresistible for risk management in two dominant discourses in contemporary Western societiesconsumption and crime. The panoply of agencies tasked with 'keeping us safe', from police, immigration, military to corporate security firms and consultancies, is making use of crime mapping and geographic profiling with the goal of identifying 'suspect' individuals and interdicting them on the basis of their sociospatial behaviour patterns. This is most readily apparent in terms of air travel (Lyon, 2003b). In the arena of consumption, the last two decades have seen the development of a geodemographics industry which draws in evermore detailed social and territorial capta to produce segmentations of space in terms of 'purchasing power' and fetishised lifestyles. Although it is often portrayed in a positive light, there are negative consequences to geodemographics (Curry, 1997; Goss, 1995). For example, the ability to determine the kinds of people who live in particular places, and their propensity to consume, implies an inherent ranking based on 'worth' and has led to discriminatory practices, such as the 'redlining' of communities deemed unprofitable or high risk by insurers and banks.

\section{Conclusion}

In this paper we have provided an analytic framework for thinking through the role of identification codes in Western society, an easily overlooked but vital part of the 'technological unconscious' (Thrift, 2004). Utilising a Foucaultian approach, we have illustrated the salience of identification codes in the governance of society and the managing of organisations and businesses through a variety of examples. Our thesis is that the application and automatic processing of digital identification codes are key to the evolving forms of contemporary governmentality and capitalism. They provide a means of representing, sorting, collating, matching, profiling, regulating, of generating information, knowledge, and control through processes of abstraction, computation, modeling, and classification. Identification codes take on special significance because 
they are a key form of capta providing the vital links between separate strands of capta. Being able to monitor and process identification codes thus provides a certain power to owners and users by enabling access and analysis of valuable capta and then to act on this knowledge (to vet, to segment, to authorise, to upgrade, to regulate, and so on). As our simple typology demonstrated, identification codes now provide a means of addressing all the entities and processes that make up everyday life-people, material objects, information, transactions, and territorial units. What is more they provide a means of linking these entities and processes together in complex ways to form a dense rhizomic assemblage, creating information and knowledge that not so long ago was the preserve of science fiction. At present, however, the capta which identification codes provide access to are, at best, oligopticons: that is, they afford only partial and selective views.

The four trends we outlined-voracious capta generation, increased granularity, forever storage, and enhanced capta processing and analysis-convert these partial oligopticons into more panoptic arrangements: that is, to offer a more detailed and yet wider ranging and continuously updating view composed of several, interlinked capta shadows, which can be data mined by using more sophisticated techniques. In turn, we contend that these trends are part of a larger metatrend - the creation of a machine-readable world in which all entities are assigned identification codes which can be 'read' and acted on by software independent of human control. They work to eliminate the messy, subjective realities of everyday life, ordering and objectifying people, striving to make them consistently addressable by software. Drawing on our Foucaultian framework, this metatrend is supported by interlocking discourses such as safety, security, efficiency, antifraud, citizenship and consumer empowerment, productivity, reliability, flexibility, economic rationality, and competitive advantage to construct powerful discursive regimes. Contra Foucault, these discourses and regimes work not only by disciplining people to their logic, but because they are seductive. Following Althusser (1971) they induce a process of interpellation wherein people willingly and voluntarily subscribe to and desire their logic.

Clearly the trends we have detailed, in combination with the discursive regimes which provide a driving logic to their implementation, have significant implications with regard to issues of privacy, confidentiality, community equity, and the organisation and functioning of society. That said, although we believe that the overall trajectory of the trend towards a machine-readable world is firmly set, we would reject strongly a techno-deterministic reading of this trend and acknowledge the contingency and inevitable variability in how technologies are being, and will be, deployed by institutions and operated by people in practice. One needs always to be alert to and sceptical of the often extravagant claims to the power of identification made by the technology vendors and their supporters in business and government, particularly so in the current scramble for homeland security monies which are relatively free flowing in many Western countries at the time of writing. Moreover, in spite of the intensity and sophistication of contemporary identification coding systems, they remain open to resistance and subversion, as the lucrative market in fake identities for underage drinkers and the growth in identity-theft crimes clearly testify. The extent, individual motivations, and implications of resistance to machine-readability are debatable and a full analysis of these consequences and implications is beyond the scope of this paper. Suffice to say, given that identification codes are becoming more prevalent, embedded in everyday life, refined in nature, spatially referenced, interlinked, and open to sophisticated analysis, their importance as means of governing populations and managing organisations is becoming more pervasive. As such, these codes of life and their supporting discursive regimes are worthy of further analysis. 
Acknowledgements. We are grateful to the instructive and positive comments of Muki Haklay, Darren Williams, and the three anonymous referees.

\section{References}

Alexander P M, 2002 Towards Reconstructing Meaning when Text is Communicated Electronically unpublished PhD thesis, Faculty of Engineering, Built Environment and Information Technology, University of Pretoria, Pretoria, http://upetd.up.ac.za/thesis/available/etd-08192002-155431/ unrestricted/00front.pdf

Alonso W, Starr P, 1987 The Politics of Numbers (Russell Sage Foundation, New York)

Althusser L, 1971 Lenin and Philosophy and Other Essays translated by B Brewster (New Left Books, London)

Amin A, Thrift N, 2002 Cities: Re-imagining the Urban (Polity Press, Cambridge)

APACS, 2003 UK Payment Markets: Trends and Forecasts in Brief 2003 Association for Payment Clearing Services, London, http://www.apacs.org.uk

ATM and Debit News, 2003 EFT Data Book: The Complete Guide to the ATM and POS Debit Markets (Thomson Corporation and ATM and Debit News, New York), available from http://www.cardforum.com

Austen I, 2003, "Your brake pads may have something to say (by email)" New York Times 27 March, http://www.nytimes.com/2003/03/27/technology/circuits/27next.html

Barnes T J, Hannah M, 2001, "The place of numbers: histories, geographies, and theories of quantification" Environment and Planning D: Society and Space $19379-383$

Becker H, 1952, "Science, culture, and society" Philosophy of Science 19(4) 273-287

Bennett C J, 2001, "Cookies, web bugs, webcams and cue cats: patterns of surveillance on the world wide web" Ethics and Information Technology 3 197-210

Bogard W, 1996 The Simulation of Surveillance: Hypercontrol in Telematic Societies (MIT Press, Cambridge, MA)

Brown S A, 1997 Revolution at the Checkout Counter: The Explosion of the Bar Code (Harvard University Press, Cambridge, MA)

Castells M, 1996 Rise of the Network Society (Blackwell, Oxford)

Checkland P, Holwell S, 1998 Information, Systems and Information Systems: Making Sense of the Field (Wiley, Chichester, Sussex)

Clarke R, 1994a, "The digital persona and its application to data surveillance" The Information Society 10(2) 77-92, http://www.anu.edu.au/people/Roger.Clarke/DV/DigPersona.html

Clarke R, 1994b, "Human identification in information systems: management challenges and public policy issues" Information Technology and People 7(4) 6-37, http://www.anu.edu.au/ people/Roger.Clarke/DV/HumanID.html

Curry M R, 1997, "The digital individual and the private realm" Annals of the Association of American Geographers 87681 - 699

Danna A, Gandy O H, 2002, "All that glitters is not gold: digging beneath the surface of data mining” Journal of Business Ethics $\mathbf{4 0} 373$ - 386

Davies S G, 1994, "Touching big brother: how biometrics technology will fuse flesh and machine" Information Technology and People 7(4) 38 -47, http://www.privacyinternational.org/reports/ biometric.html

Deleuze G, 1992, "Postscript on the societies of control" October 59 3-7

Desrosières A, 1998 The Politics of Large Numbers: A History of Statistical Reasoning translated by C Naish (Harvard University Press, Cambridge, MA)

Dicken, P, 2003 The Global Shift 4th edition (Sage, London)

Dobson J E, Fisher P F, 2003, "Geoslavery” IEEE Technology and Society Magazine (Spring) $47-52$

Dodge M, Kitchin R, 2004, "Flying through code/space: the real virtuality of air travel" Environment and Planning A $36195-211$

Dodge M, Kitchin R, 2005, "Code and the transduction of space" Annals of the Association of American Geographers forthcoming

Dunlop J T, Rivkin J W, 1997, "Introduction" in Revolution at the Checkout Counter: The Explosion of the Bar Code Ed. S A Brown (Harvard University Press, Cambridge, MA) pp 1-38

Edney M H, 1997 Mapping an Empire: The Geographical Construction of British India, 1765 - 1843 (University of Chicago Press, Chicago, IL)

Elliot C, 2004, "Some rental cars are keeping tabs on the drivers" New York Times 13 January, http://www.nytimes.com/2004/01/13/business/13gps.html

Ferguson T, 2002, "Have your objects call my object" Harvard Business Review 1 - 7 June 
Foucault M, 1976 Discipline and Punish (Allen Lane, London)

Foucault M, 1978 The History of Sexuality volume 1 (Random House, New York)

Gandy O H, 1993 The Panoptic Sort: A Political Economy of Personal Information (Westview Press, Boulder, $\mathrm{CO}$ )

Gates K A, 2002, "Wanted dead or digitized: facial recognition technology and privacy" Television and New Media $3235-238$

Gilheany S, 2000, "Projecting the cost of magnetic disk storage over the next 10 years", White Paper 22011v039, Archivebuilders.com, Manhattan Beach, CA, http://www.archivebuilders.com/ whitepapers/22011v039h.html

Gilliom J, 2001 Overseers of the Poor: Surveillance, Resistance and the Limits of Privacy (University of Chicago Press, Chicago, IL)

Goss J, 1995, “'We know who you are and we know where you live': the instrumental rationality of geodemographics systems" Economic Geography 71 171 - 198

Graham S, 2004, "The software-sorted city: rethinking the 'digital divide",, in The Cybercities Reader Ed. S Graham (Routlege, London) pp 324-331

Grochowski E, Halem R D, 2003, "Technological impact of magnetic hard disk drives on storage systems" IBM Systems Journal $42338-346$

Haklay M, 2001 Public Environmental Information Systems: Challenges and Perspectives unpublished $\mathrm{PhD}$ thesis, Department of Geography, University College London, London, http://www.casa.ucl.ac.uk/muki/thesis.htm

Hannah M, 1992 Foucault Deinstitutionalised: Spatial Prerequisites for Modern Social Control unpublished PhD thesis, Department of Geography, Pennsylvania State University, University Park, PA

Hannah M, 1997a, "Space and the structuring of disciplinary power: an interpretative review" Geografiska Annaler Series B, Human Geography 79171 -180

Hannah M, 1997b, "Imperfect panopticism: envisioning the construction of normal lives", in Space and Social Theory Eds G Benko, U Strohmayer (Blackwell, Oxford) pp 344-360

Harmon C K, 1994 Lines of Communication: Bar Code and Data Collection Technology for the 90s (Helmers, Peterborough, NH)

Harvey D, 1982 The Limits to Capital (Blackwell, Oxford)

Home Office, 2004 Legislation on Identity Cards: A Consultation Cm 6178, http://www.homeoffice.gov.uk/ docs3/identitycardsconsult.pdf

Hosoya H, Schaefer M, 2001, "Bit structures", in Harvard Design School Guide to Shopping Eds C J Chung, J Inaba, R Koolhaas, S T Leong (Taschen, Köln) pp 156-162

Innes M, 2001, "Control creep" Sociological Research Online 6(3), http://www.socresonline.org.uk/6/ 3/innes.html

Jensen H E, 1950, "Editorial note", in Through Values to Social Interpretation H Becker (Duke University Press, Durham, NC)

Johnson H B, 1976 Order Upon the Land: The U.S. Rectangular Land Survey and the Upper Mississippi Country (Oxford University Press, New York)

Lander E, 1992, "DNA fingerprinting: science, law and the ultimate identifier", in The Code of Codes: Scientific and Social Issues in the Human Genome Project Eds D J Kevles, L Hood (Harvard University Press, Cambridge, MA) pp $191-210$

Larson E, 1992 The Naked Consumer: How Our Private Lives Become Public Commodities (Henry Holt, New York)

Lazinger S S, 2001 Digital Preservation and Metadata: History, Theory, Practice (Libraries Unlimited, Englewood, CO)

Leibowitz E, 1999, "Bar codes: reading between the lines" Smithsonian February, 29(11) 130 - 146

Lessig L, 2004 Free Culture: How Big Media Uses Technology and the Law to Lock Down Culture and Control Creativity (Penguin Books, New York)

Leyshon A, Thrift N, 1999, "Lists come alive: electronic systems of knowledge and the rise of credit-scoring in retail banking" Economy and Society 28 434-466

Lianos M, Douglas M, 2000, "Dangerization and the end of deviance: the institutional environment" British Journal of Criminology $40261-278$

Lyon D, 2002, "Everyday surveillance: Personal data and social classifications" Information, Communication and Society $5242-257$

Lyon D, 2003a, "Surveillance as social sorting: computer codes and mobile bodies", in Surveillance as Social Sorting: Privacy, Risk and Digital Discrimination Ed. D Lyon (Routledge, London)

pp $13-30$ 
Lyon D, 2003b, "Airports as data filters: converging surveillance systems after September 11th" Information, Communication and Ethics in Society $113-20$

Mackenzie A, 2002 Transductions: Bodies and Machines at Speed (Continuum Press, London)

McNay L, 1994 Foucault: A Critical Introduction (Polity Press, Oxford)

Meek J, 2002, "Robo cop" The Guardian 13 June, http://www.guardian.co.uk/Archive/Article/ $0,4273,4432506,00 \cdot \mathrm{html}$

Miller H J, Han J, 2001, "Geographic data mining and knowledge discovery: an overview", in Geographic Data Mining and Knowledge Discovery Eds H J Miller, J Han (Taylor and Francis, London) pp $3-32$

Morton A Q, 1994, "Packaging history: the emergence of the uniform product code (UPC) in the United States, 1970 - 75" History and Technology $11101-111$

Orwell G, 1987 Nineteen Eighty-Four (Penguin Books, London); first published in 1949

Palmer R C, 1995 The Bar Code Book: Reading, Printing, Specification, and Application of Bar Codes and Other Machine Readable Symbols 3rd edition (Helmers, Peterborough, NH)

Paskin N, 2003, "Identification and metadata", in Digital Rights Management: Technological, Economic, Legal and Political Aspects Eds E Becker, W Buhse, D Günnewig, N Rump (Springer, Berlin) pp 26-61

PCSA, 2002, "Joined-up geography", in PFI/PPP: 2002 Report (PCSA International Ltd, London), http://www.publicservice.co.uk/pdf/pfi/winter2001/p182.pdf

Phillips D J, 2003, "Beyond privacy: confronting locational surveillance in wireless communications" Communication Law and Policy $81-23$

Porter T M, 1995 Trust in Numbers: The Pursuit of Objectivity in Science and Public Life (Princeton University Press, Princeton, NJ)

Rhind D, 1997 Framework for the World (Wiley, New York)

Rose N, 1996 Inventing Our Selves: Psychology, Power and Personhood (Cambridge University Press, Cambridge)

Rule J B, McAdam D, Stearns L, Uglow D, 1983, “Documentary identification and mass surveillance in the United States" Social Problems 31(2) 222-234

Savir D, Laurer G J, 1975, "The characteristics of and decodability of the universal product code" IBM Systems Journal 14 16-35

Schoenberger C R, 2002, “The internet of things” Forbes Magazine 18 March, http://www.forbes.com/ technology/forbes/2002/0318/155.html

Solzhenitsyn A, 1968 Cancer Ward Part I, translated by N Bethell, D Burg (Bodley Head, London)

Stalder F, 2002, "Privacy is not the antidote to surveillance" Surveillance and Society 1(1) 120 - 124, http://www.surveillance-and-society.org/articles1/opinion.pdf

Thrift N, 2002, "Driving in the city", mimeo, http://www.its.leeds.ac.uk/projects/mobilenetwork/ downloads/driving_in_the_city.doc

Thrift N, 2004, "Remembering the technological unconscious by foregrounding knowledges of position" Environment and Planning D: Society and Space $22175-190$

Thrift N, French S, 2002, "The automatic production of space" Transactions of the Institute of British Geographers, New Series $27309-335$

Torpey J, 2000 The Invention of the Passport: Surveillance, Citizenship, and the State (Cambridge University Press, Cambridge)

Torpey J, Caplan J, 2001 Documenting Individual Identity: The Development of State Practices in the Modern World (Princeton University Press, Princeton, NJ)

Triglav J, 2002, "OS MasterMap, heralding a new era in GIS applications" GeoInformatics Magazine January/February, $12-15$

Want R, Fishkin K, Gujar A, Harrison B, 1999, "Bridging physical and virtual worlds with electronic tags" Proceedings of SIGCHI Conference pp 370 - 377, http://doi.acm.org/10.1145/ 302979.303111

Watson J, Crick F, 1953, “A structure for deoxyribose nucleic acid” Nature 1712 April, 753

Wired News 2003, "Mad cow spurs livestock tracking” Wired News 31 December, http://www.wired.com/ news/medtech/0,1286,61770,00.html

Wise M N, 1995 The Values of Precision (Princeton University Press, Princeton, NJ) 
